IMPLEMENTASI KEBIJAKAN PENINGKATAN PROFESIONALISME

GURU SMP NEGERI 3 HU'U KABUPATEN DOMPU

NUSA TENGGARA BARAT

\title{
TESIS
}

Untuk Memenuhi Sebagian Persyaratan

Derajat Gelar S-2

Program Studi Magister Kebijakan dan Pengembangan Pendidikan

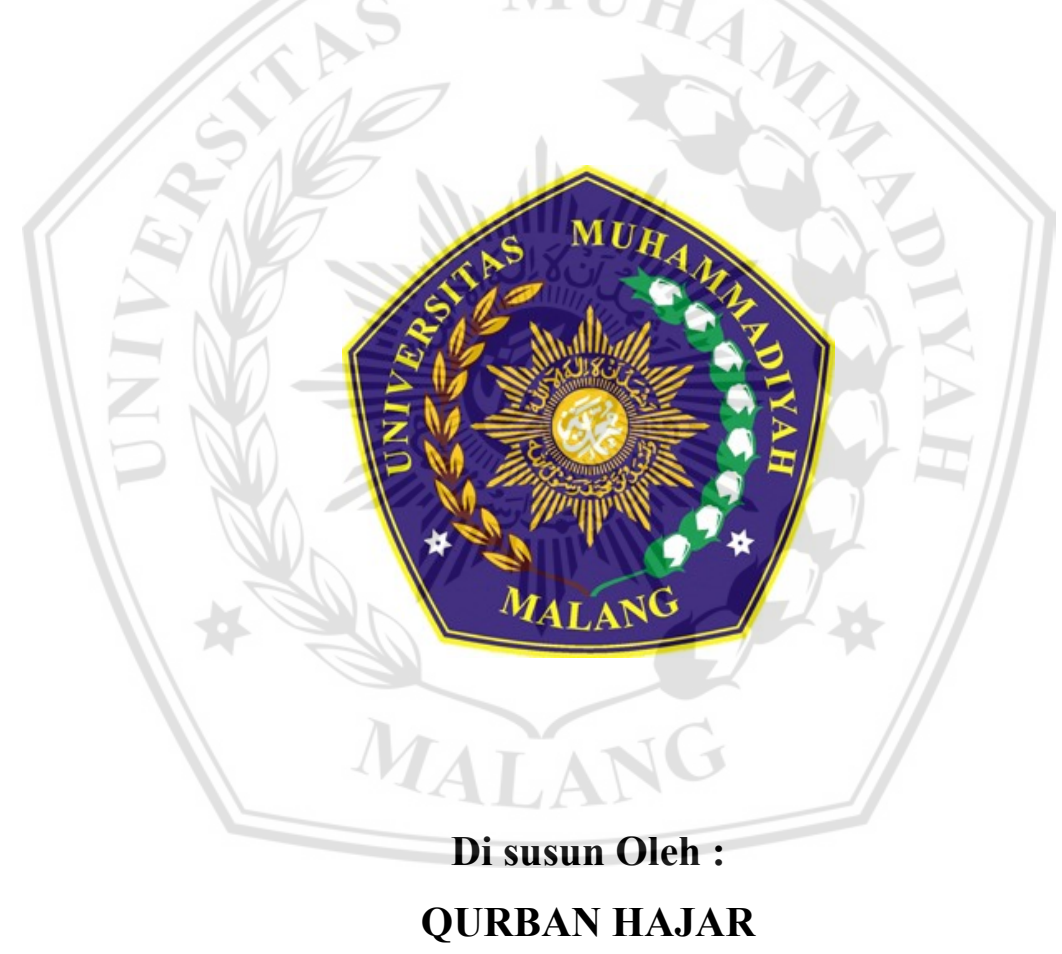

NIM: 201810240211004

DIREKTORAT PROGRAM PASCASARJANA

UNIVERSITAS MUHAMMADYAH MALANG

Januari 2020 


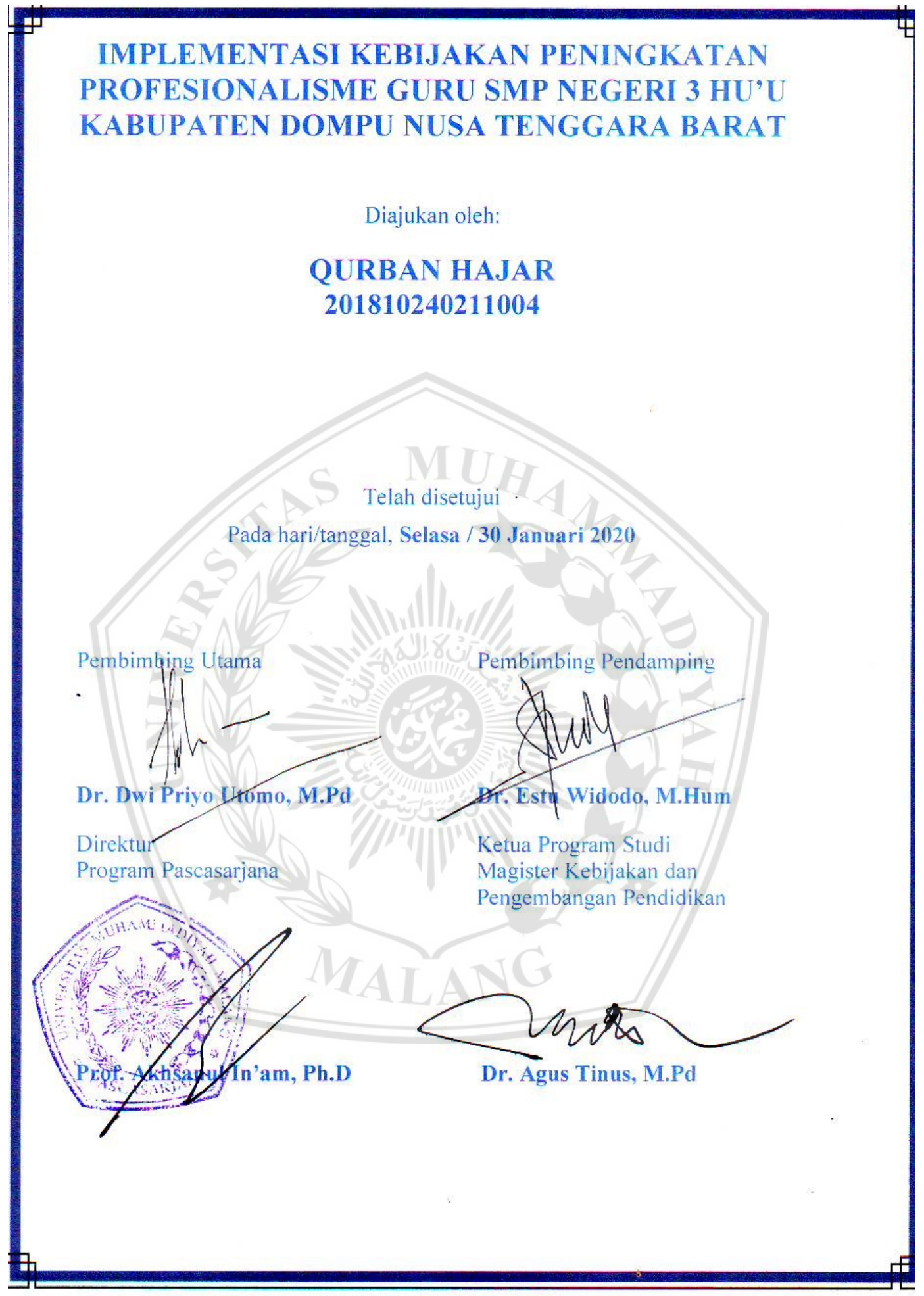




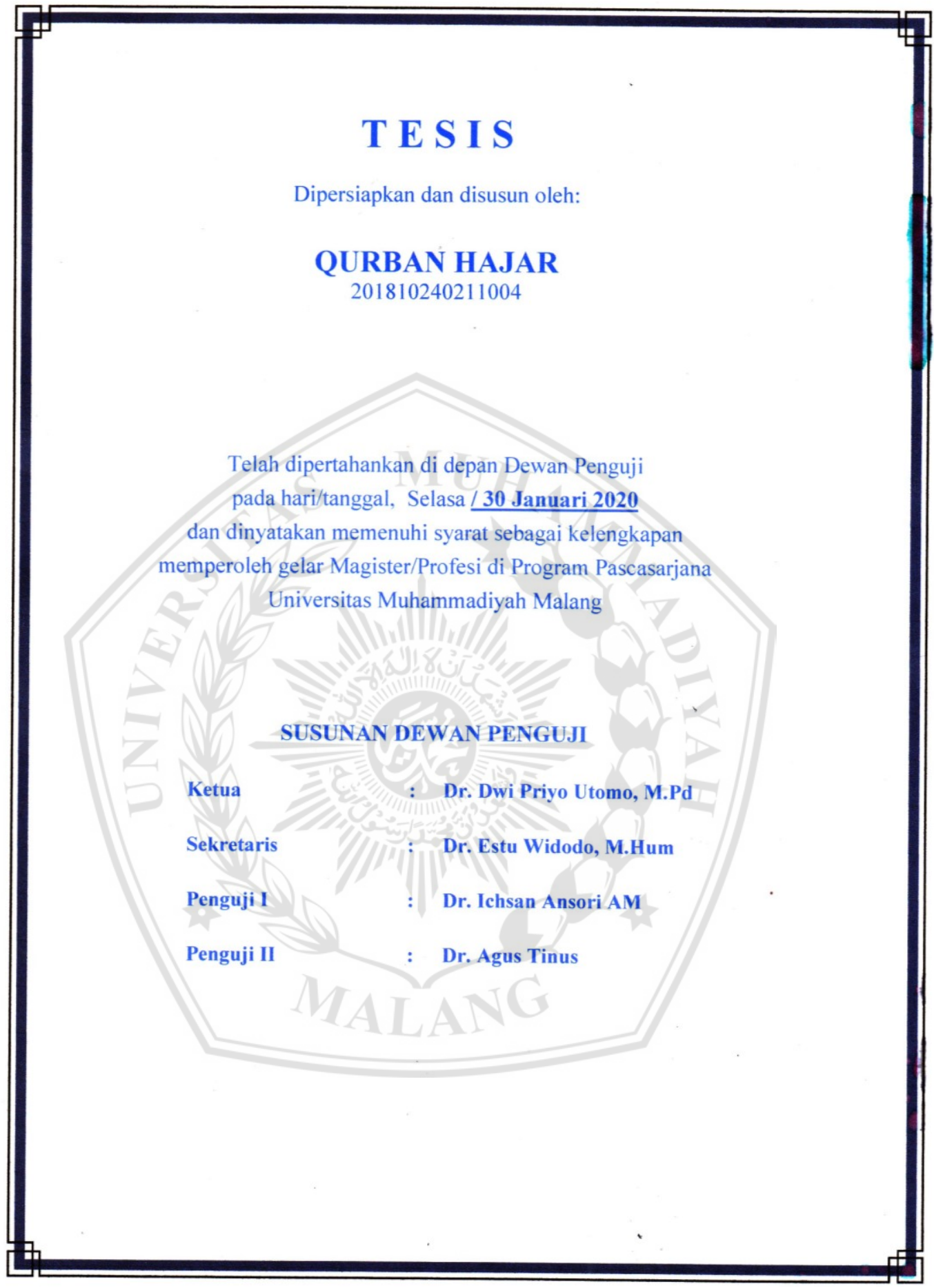




\section{SURAT PERNYATAAN}

Yang bertanda tangan di bawah ini, saya:

Nama : QURBAN HAJAR

NIM

: 201810240211004

Program Studi : Magister Kebijakan dan Pengembangan Pendidikan

Dengan ini menyatakan dengan sebenar-benarnya bahwa :

1. TESIS dengan judul: IMPLEMENTASI KEBIJAKAN PENINGKATAN PROFESIONALISME GURU SMP NEGERI 3 HU'U KABUPATEN DOMPU NUSA TENGGARA BARAT. Adalah karya saya dan dalam naskah Tesis ini tidak terdapat karya ilmiah yang pernah diajukan oleh orang lain untuk memperoleh gelar akademik di suatu Perguruan Tinggi dan tidak terdapat karya atau pendapat yang pernah ditulis atau diterbitkan oleh orang lain, baik sebagian maupun keseluruhan, kecuali yang secara tertulis dikutip dalam naskah ini dan disebutkan dalam sumber kutipan dalam daftar pustaka.

2. Apabila ternyata dalam naskah Tesis ini dapat dibuktikan terdapat unsur-unsur PLAGIASI, saya bersedia Tesis ini DIGUGURKAN dan GELAR AKADEMIK YANG TELAH SAYA PEROLEH DIBATALKAN, serta diproses sesuai dengan ketentuan hukum yang berlaku.

3. Tesis ini dapat dijadikan sumber pustaka yang merupakan HAK BEBAS ROYALTY NON EKSKLUSIF.

Demikian pernyataan ini saya buat dengan sebenarnya uniuk dipergunakan sebagaimana mestinya.

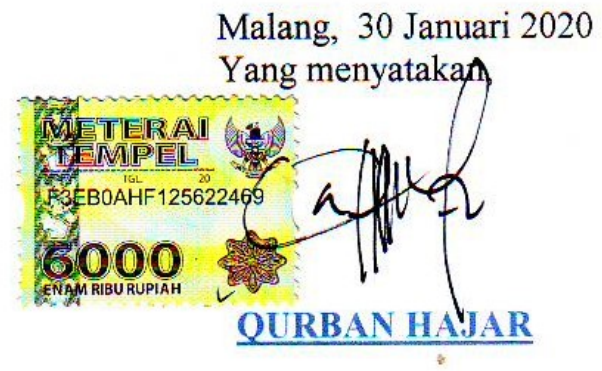




\section{KATA PENGANTAR}

Puji syukur kehadirat Allah SWT yang telah melimpahkan rahmat dan karunia-Nya, sehingga tesis yang berjudul " Implementasi Kebijakan Peningkatan Profesionalisme Guru SMP Negeri 3 Hu'u Kabupaten Dompu Nusa Tenggara Barat" dapat terselesaikan sesuai dengan waktu yang telah ditentukan.

Selama penyusunan tesis ini, penulis menyadari bahwa semua tidak akan selesai dengan baik tanpa bimbingan, motivasi dan bantuan baik secara langsung maupun tidak langsung dari berbagai pihak. Maka dari itu, penulis mengucapkan terimakasi banyak kepada:

1. Prof. Akhsanul In'am, Ph.D., selaku Direktur Program Pascasarjana Universitas Muhammadiyah Malang.

2. Dr. Agus Tinus, M.Pd., selaku Ketua Prodi Magister Kebijakan dan Pengembangan Pendidikan.

3. Dr. Dwi Priyo Utomo, M.Pd., selaku dosen pembimbing utama yang telah banyak meluangkan waktu, membimbing dan mengarahkan dengan sabar, serta memberikan saran dalam penyelesaian tesis.

4. Dr. Estu Widodo, M.Hum., selaku dosen pembimbing pendamping yang selalu sabar membimbing dan menyediakan waktu serta memberikan saran dalam menyempurnakan tesis.

5. Segenap staf pengajar Program Studi Magister Kebijakan dan Pengembangan Pendidikan yang telah banyak memberikan saran dalam penyempurnaan tesis.

6. Kedua orang tua saya, I yang selalu mendoakan, memberikan restu serta memotivasi dalam menyelesaikan tesis hingga tahap akhir.

7. Teman-teman MKPP A angkatan 2018 tanpa terkecuali yang telah bersamasama berjuang dan saling menyemangati sehingga penulis menyadari arti kebersamaan dan persaudaraan dalam satu perjuangan.

Malang, 30 Januari 2020 


\section{PERSEMBAHAN}

"Keberhasilan itu hanya bisa dilakukan oleh diri sendiri bukan orang lain

"K eberhasilan bukanlan berapa banyak yang kita dapatkan tetapi berapa banyak yang dapat berikan serta berarti untuk orang lain"

Qs. Al $\operatorname{Ar} a f(7)$

Artinya: Berdoalah kepada tuhanmu dengan berendah diri dan suara yang lembut. sesungguhnya Allah tidak menyukai orang-orang yang melampaui batas.

Jangan sedíh bíla anakmu tídak dapat ranking kuliah. Tapi sedíhlah bila anakmu tidak sholat, ngaji, tidak jujur dan tidak berbakti pada kedua orangtua. Ranking hanya kebanggaan sementara, sedangkan akhlak mulia harapan dan kebangaanmu dunia akhirat

Tesisini sya persembahkan untuk kedua orang tua tersayang

ibrarim H. A Hamid

imo ibrahim

Teman sekelas A MKPP, Mba Melly, Mba Husnita, Mba Dian, Mas faizal, Mas Yusuf, Mas Britio

Adík - adíkku, ponaan - ponaanku, saudarah - saudarahku, dan Keluarga Besar H. A Hamid dan A. Halike dan tidak lupa Keluarga besar FKMPD, KAPAHU yang telah memberikan sewmangkat, Motivasi yang saat luar biasa.

Almamater yang aku cintaí. 


\begin{abstract}
ABSTRAK
Qurban Hajar. 2019 Implementasi Kebijakan Peningkatan Profesionalisme Guru SMP Negeri 3 Hu'u Kabupaten Dompu Nusa Tenggara Barat . Tesis Program Studi Magister Kebijakan dan Pengembangan Pendidikan, Program Pascasarjana Universitas Muhammadyah Malang, Pembimbing: I) Dr. Dwi Priyo Utomo, M.Pd, ( NIND 0026026201). II) Dr. Estu Widodo, M.Hum, (NIND 0020056801) E_mail: qurbanhajar69@gmail.com
\end{abstract}

Guru profesional dapat menggerakkan dinamika kemajuan pendidikan nasional, untuk itu diperlukan suatu proses pembinaan berkesinambungan, tepat sasaran dan efektif. Proses untuk meningkatkan guru profesional perlu dukungan semua unsur yang terkait dengan guru. Unsur-unsur tersebut dapat dipadukan untuk menghasilkan suatu sistem yang dapat bekerja menuju pembentukan guru-guru yang profesional dalam kualitas maupun kuantitas yang mencukupi. Penelitian ini bertujuan untuk mendeskripsikan Implementasi Kebijakan Peningkatan Profesionalisme Guru SMP Negeri 3 Hu'u Nusa Tenggara Barat. Penelitian ini juga menggunakan pendekatan deskriptif kualitatif dengan metode pengumpulan data berupa obsevasi, wawancara, dan studi dokumen yang dijadikan sebagai sumber data primer dan data sekunder. Data primer diperoleh dari hasil observasi dan wawancara terhadap Kepala Sekolah dan Guru. Data Sekunder berupa dokumen data-data yang mendukung untuk memperkuat Analisis Kebijakan Sekolah dalam Peningkatan Profesionalisme Guru SMP Negeri 3 Hu'u Kabupaten Dompu. Hasil penelitian menunjukkan bahwa: 1) pelaksanaan kegiatan MGMP, PKB, Diklat, pengembangan kurikulum dari ketiga sekolah tersebut masih kurang, karena tidak semua guru-guru dikirim dalam kegiatan-kegiatan tersebut. Serta kurangnya kesiapan kompetensi professional guru pada sektor pengembangan diri dan pemanfaatan teknologi, informasi dan komunikasi. 2) Kendala yang dihadapi dalam pelaksanaan peningkatan profesionalisme guru adalah pengembangan keprofesionalan secara berkelanjutan yaitu kurangnya pemahaman guru terhadap materi ajar, dan kurangnya kesempatan untuk mengikuti pelatihan-pelatihan sebagai penunjang menjadi guru profesional. 3) Upaya terhadap kendala yang dihadapi dalam pelaksanaan peningkatan profesionalisme guru sudah dilaksanakan terkait pelaksanaan PKB, MGMP, pengembangan kurikulum, diklat pada tingkat sekolah, daerah, maupun provinsi tetapi pencapaian tersebut belum sepenuhnya maksimal. Dinas pendidikan maupun sekolah perlu terus mengupayakan peningkatan profesionalisme guru. Analisis ini berdampak pada terciptanya penyelenggaraan pendidikan yang lebih baik, meningkatkan kinerja dan kualitas guru untuk menjadi guru yang professional, dan terwujudnya pemahaman masyarakat terhadap pentingnya pendidikan.

Kata Kunci: Kebijakan Sekolah, Peningkatan Profesionalisme, Guru 


\begin{abstract}
Qurban Hajar 2019. The Implementation of Policies on Improving Professionslism of Teachers in Junior High School 3 Hu'u of Dompu Eity West Nusa Tengara Barat Tesis Program Studi Magister Kebijakan dan Pengembangan Pendidikan, Program Pascasarjana Universitas Muhammadyah Malang, Pembimbing: : I) Dr. Dwi Priyo Utomo,M.Pd, ( NIND 0026026201).II) Dr. Estu Widodo, M.Hum, (NIND 0020056801 )

E_mail: qurbanhajar69@gmail.com
\end{abstract}

Professional teachers can move the dynamics of the progress of national education, for that a continuous, targeted and effective development process is needed. The process to improve professional teachers needs to support all elements related to the teacher. These elements can be combined to produce a system that can work towards the formation of teachers who are professional in sufficient quality and quantity. This study aims to describe school policy in increasing teacher professionalism in the Junior High School $3 \mathrm{Hu}$ 'u. This study also uses a qualitative descriptive approach with data collection methods in the form of observation, interviews, and study of documents which are used as sources of primary data and secondary data. Primary data is obtained from the results of observations and interviews with Principals and Teachers. Secondary data in the form of data documents that support to strengthen School Policy The Implementation of Policies on Impoving Professionalism of Teachers Junior in High School $3 \mathrm{Hu}$ 'u. The results showed that: 1) the implementation of MGMP activities, PKB, Diklat, curriculum development from the three schools was still lacking, because not all teachers were sent in these activities. And the lack of readiness of professional competence of teachers in the self-development sector and the use of technology, information and communication. 2) Constraints faced in implementing teacher professionalism are continuous development of professionalism, namely the lack of teacher understanding of teaching materials, and the lack of opportunities to take part in training as supporting professional teachers. 3) Efforts towards the obstacles faced in implementing teacher professionalism have been carried out related to the implementation of PKB, MGMP, curriculum development, training at the school, regional and provincial levels but these achievements have not been fully maximized. The education and school offices need to continue to strive to improve teacher professionalism. This analysis has an impact on the creation of better education, improved teacher performance and quality to become professional teachers, and the realization of a public understanding of the importance of education.

Keywords: The Implementation of Policies, Increasing Professionalism, on Improving 


\section{DAFTAR ISI}

\section{Halaman Judul}

LEMBAR PERSETUJUAN ............................................................................. i

LEMBAR SUSUNAN DEWAN PENGUJI ............................................. ii

SURAT PERNYATAAN ........................................................................ iii

KATA PENGANTAR .............................................................................. iv

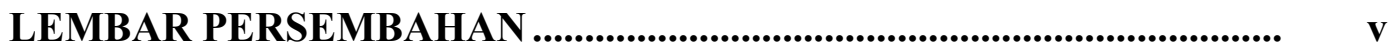

ABSTRAK .................................................................................... vi

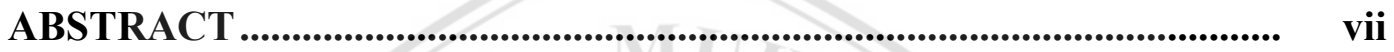

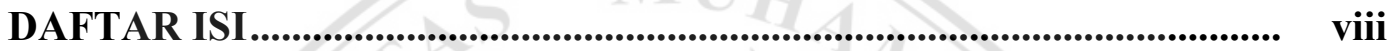

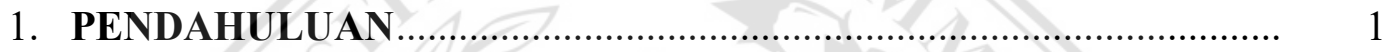

2. TINJAUAN PUSTAKA …................................................................. 4

2.1 Guru Profesional .................................................................... 4

a. Kompetensi Guru.......................................................... 6

b. Kedudukan Guru............................................................... 7

2.2 Kebijakan Peningkatan Profesionalisme Guru ............................... 8

a. Pengembangana Profesian Berkelanjutan ................................... 8

b. Esensi Kode Etika Profesi .......................................................... 10

2.3 Kompetensi Guru ....................................................................... 11

2.4 Implementasi Kebijakan Guru ................................................. 11

2.5 Kebijakan Untuk Peningkatan Profesional Guru........................... 12

3. METODE PENELITIAN .......................................................... 13

3.1 Pendekatan Penelitian .................................................................... 13

3.2 Lokasi Penelitian.......................................................................... 13

3.3 Insrumen Penelitian .............................................................. 14

3.4 Data dan Sumber Penelitian ............................................................... 14

3.5 Teknik Pengumpulan Data.......................................................... 14

3.6 Teknik Analisis Data.................................................................. 14

3.7 Uji Keabsahan Data ................................................................ 15 
4. HASIL PENELITIAN ….......................................................... 15

4.1 Hasil Penelitian ...................................................................... 15

4.2 Kebijakan sekolah dalam Peningkatan Profesionalisme Guru di SMP Negeri 3 Hu'u ................................................................. 16

4.3 Kendala yang dihadapi Peningkatan Profesionalisme Guru di SMP Negeri 3 Hu'u ................................................................. 18

4.4 Upaya Peningkatan Keprofesionalisme Guru di SMP Negeri 3 Hu'u 18

4.5 Pengembangan Keprofesionalisme Berkelanjutan ........................... 19

4.6 Kompetensi Profesionall ................................................................ 21

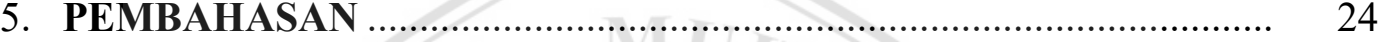

6. KESIMPULAN_............................................................................................. 27

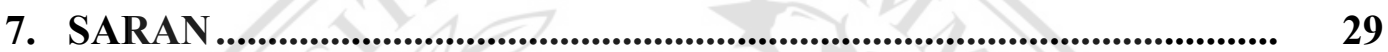

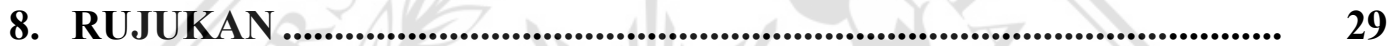
LAMPIRAN 


\section{PENDAHULUAN}

Guru Profesional yang memiliki keahlian dan kewenangan dalam pendidikan, pengajaran dan pelatihan membutuhkan kemampuan khusus dalam menguasai proses pembelajaran. Guru yang memiliki profesi sebagai pekerja disertakan kompetensi dalam melaksanakan pengajaran yang efektif dan efisien. Guru profesional perlu mengemas dan merancang pembelajaran sebaik mungkin agar peserta didik lebih aktif dalam menerima pembelajaran (Dwi Kesuma Putri, Imaniyati, 2017).

Berdasarkan Undang - undang Peraturan Menteri Nomor 18 tahun 2007 menyatakan baghwa guru wajib memiliki kualifikasi akademik, kompetensi sertifikasi pendidik, sehat jasmanii dan rohani, serta memiliki kemampuan untuk mewujudkan tujuan pendidikan nasional. Pengakuan kedudukan guru sebagai tenaga professional dibuktikan dengan sebuah sertifikasi guru. Sertifikasi guru adalah bukti formal pengakuan yang diberikan kepada guru sebagai tenaga profesional (1) kompetensi pedagogik, (2) kompetensi kepribadiann, (3) kompetensi sosial, dan (4) kompetensi profesional yang diperoleh melalui pendidikan profesi.

Sertifikasi guru dapat melalui proses yang dibuat sertifikasi guru. Sertifikasi pendidik diberikan kepada guru yang telah memenuhi persyaratan. Sertifikasi pendidik diselenggarakan oleh perguruan tinggi yang memiliki program pengadaan tenaga pendidikan yang terakreditasi dan ditetapkan oleh pemerintah peraturan mentri di atas landasi dilaksanakan sertifikasi guru yang baru- baru ini.

Syarat menjadi guru profesional adalah mampu menjalankan ketentuan dan syarat yang berlaku sesuai dengan Peraturan Pemerintah No 74 Tahun 2008 yang mengatakan bahwa guru sekurang-kurangnya harus memiliki empat kompetensi dalam pengajaran antara lain kompetensi pedagogik, kompetensi profesional, kompetensi kepribadian dan kompetensi sosial (Eka, el al 2016). Guru merupakan tenaga profesional yang memiliki kualifikasi akademik yang baik, kualitas kompetensi yang baik, sertifikat pendidikan, serta memiliki kemampuan untuk mewujudkan tujuan pendidikan guru harus mampu meningkatkan kualitas diri sesuai dengan perkembangan zaman (Lion, 2015; Hasbullah, 2015). Guru sebagai 
salah satu profesi tertua di dunia. Berada pada tingkat tertinggi dalam sistem pendidikan nasional dan sangat strategis karena mengemban tugas sejati serta memiliki otonomi yang kuat, seperti proses kemanusian, pencerdasaan, pembudayaan, dan membangun karakter bangsa (Lion, 2015; Suhandani, 2014). Seorang guru harus mampu menjawab tantangan zaman, karena guru adalah pemimpin pendidikan yang sangat menentukan proses pembelajaran di dalam kelas. Guru yang profesional adalah guru yang memiliki idealisme dan kepribadian yang baik (Hasbullah, 2015).

Profesi guru diselenggarakan melalui pengembangan diri yang dilakukan secara demokratis, berkeadilan, tidak diskriminatif, dan berkelanjutan dengan menjunjung tinggi hak asasi manusia, nilai keagamaan, nilai kultural, kemajemukan bangsa, dan kode etik profesi. Disamping itu menurut pasal 20, dalam melaksanakan tugas keprofesionalan, guru berkewajiban meningkatkan dan mengembangkan kualifikasi akademik dan kompetensi secara berkelanjutan sejalan dengan perkembangan ilmu pengetahuan, teknologi, dan seni.

Menurut Putri dkk., (2017) kebijakan adalah sebagai spesifikasi implisit atau eksplisit dari serangkain tujuan tindakan yang diikuti berkaitan dengan pengenalan masalah. Sementara Sujendra Diputra \& Ketut Desia Tristiantari, (2016) sebagai label untuk bidang kegiatan, kebijakan suatu ekspresi umum dari tujuan umum atau pendiri yang dikembangkan untuk merespon masalah atau konflik yang diarahkan untuk mencapai tujuan tertentu.

Berbagai masalah yang berkaitan dengan kondisi guru antara lain; 1) adanya keberagaman kemampuan guru dalam proses pembelajaran; 2) pembinaan yang dilakukan belum mencerminkan kebutuhan guru; 3) kesadaran guru terhadap pentingnya pengembangan diri masih kurang serta; 4) kemampuan guru dalam mengelola kelas masih kurang memadai. Jika hal tersebut tidak segera diatasi maka berdampak pada rendahnya kualitas pendidikan, antara lain; (1) kemampuan siswa dalam menyerap mata pelajaran tidak maksimal; (2) kurang sempurnanya pembentukan karakter yang tercermin dalam sikap dan kecakapan hidup yang dimiliki oleh setiap siswa (Wulandari, 2016). 
Untuk mencapai tujuan pendidikan, guru merupakan salah satu komponen penting penentu keberhasilan pendidikan. Gurulah yang berada barisan terdepan dalam melaksanakan pendidikan, oleh karena itu guru yang langsung berhadapan dengan siswa untuk menstransfer ilmu pengetahuan dan teknologi sekaligus mendidik dengan nilai-nilai positif melalui bimbingan dan keteladanan (Riyadin, 2016). Hal ini dijelaskan pula dalam UU No 20 Tahun 2003 tentang sistem pendidikan nasional pasal 1 ayat 6 , dimana yang dimaksud dengan pendidikan adalah tenaga yang berkualifikasi sebagai guru, dosen, konselor, pamong belajar, widyaiswara, tutor, intruktur, fasilitator.

Keberhasilan kepala sekolah dalam pelaksanakan program kebijakan tersebut, diasumsikan merupakan hasil dari kerja keras dan kepagawai kepala sekolah dalam membuat kebijakan-kebijakan operasional dalam peningkatan guru. Asumsi ini bertolak dari kerangka pikir bahwa kunci keberhasilan pendidikan di sekolah pada dasarnya bergantung pada kebijakan kepala sekolah dalam peningkatan profesionalisme guru dan dalam melaksanakan suatu kepemimpinan pendidikan dan cara bertindak.

Demikian pula, keberhasilan itu tentu saja tidak dapat dilepaskan dari keberhasilan kepemimpinan kepala sekolah. Kebijakan kepala sekolah dalam proses peningkatan profesionalisme guru termasuk upaya kepala sekolah untuk mengetahui kemampuan dan perilaku setiap para pengajar yang dipengaruhi tidak hanya oleh ilmu, melainkann keterampilan yang diperoleh selama peserta didik mengalami proses belajar mengajar, motivasi kerja, sikap latar belakang budaya dan pengaruh lingkungan. Kebijakan kepala sekolah dalam peningkatan profesionalisme guru SMP Negeri 3 Hu'u harus berupaya mengembangkan visi, misi dan sasaran yang ditetapkan sebelumnya.

Mengingat pentingnya peningkatkan kemampuan guru yang berdampak pada kemampuan peserta didik, maka perlu dilakukan upaya-upaya tertentu, antara lain: 1) pelatihan dan pembinaan pengembangan guru, 2) pengarahan kepada guru terhadap pentingnya meningkatkan kemampuan yang dimiliki sehingga diharapkan proses kegiatan belajar mengajar mengalami peningkatan. 
Sekolah SMP Negeri 3 Hu'u merupakan sekolah yang berada di wilayah kecamatan Hu'u Kabupaten Dompu Nusa Tenggara Barat dengan keberagaman sekolah dengan jumlah guru sebanyak empat puluh empat guru merupakan tantangan tersendiri bagi seorang kepala sekolah dalam memanfaatkan kemampuan dan kecakapan para tenaga pendidikanya. kepala sekolah merupakan tolak ukur keberhasilan suatu sekolah menjadikan sekolah itu berhasil dan tidak dalam mengembangkan sumber daya guru maupun peserta didiknya, kepala sekolah SMP Negeri 3 Hu'u diangkat menjadi kepala sekolah tersebut dengan harapan dapat membawa perubahan terhadap sekolah yang dipimpin dengan menciptakan inovasi/ kreatifitas agar sekolah tersebut menjadi sekolah yang ungul dan mampu bersaing dengan sekolah-sekolah lain dengan cara meningkatkan kualitas tenaga pendidik dan peserta didik.

Berdasarkan latar belakang tersebut, masalah yang akan dijawab dalam penelitian ini adalah: (1) Bagaimana Implementasi Kebijakan Peningkatan Profesionalisme Guru SMP Negeri 3 Hu'u? (2) Kendala Dalam Peningkatan Profesionalisme Guru SMP Negeri 3 Hu'u? (3) Upaya Peningkatan Profesionalisme Guru SMP Negeri 3 Hu'u.

\section{KAJIAN PUSTAKA}

\subsection{Guru Profesional}

Guru profesional menjalankan profesinya harus sungguh-sungguh dalam mengusai empat kompetensi diantaranya kompetensi pedagogik, kompetensi profesional, kompetensi kepribadian dan kompetensi sosial sebagai persyaratan penguasaan kompetensi (Ayu, Agung, \& Suarni, n.d., 2015). Guru sebagai agen pendidik tersebut memperhatikan tujuan dari pendidikan agar dapat terlaksana dengan baik, guru yang merupakan pendidik yang profesional dapat memberikan pelayanan pendidik yang baik terhadap peserta didiknya sebagai bentuk keberhasilan pendidik dalam menjalankan tugasnya sebagai guru yang profesional (Jailani, 2009; Wulandari, 2016 )

Desain Guru Profesional Pemerintah telah merencanakan beberapa kebijakan untuk meningkatkan profesionalisme guru dalam melaksanakan tugas, antara lain 
berupa program sertifikasi guru, uji kompetensi guru, penilaian kinerja guru, program induksi bagi guru pemula, serta pengembangan keprofesian berkelanjutan melalui permenpan dan Reformasi Birokrasi Nomor 16 tahun 2009. Akan tetapi kebijakan tersebut belum dilengkapi dengan teknik operasional dalam melakukan pembinaan guru secara efektif.

Profesi dabn profesionalisme adalah hal yang berkaitan. Profesi didefiniskan sebagai sebuah setiap pekerjaan yang diggeluti dengan penuh pengabdian dan didekasi serta profesionalisme guru dalam kamus besar bahasa Indonesia adalah mutu, kualitas tindak lanjut yang merupakan ciri suatu profesi atau orang yang profesional.

Profesionalisme guru adalah sikap profesional yang berarti melakukan sesuatu sebagai pekerjaan \, sebagai profesi dan bukan sebagai pengisi waktu luang atau sebagai hobi belaka. Seorang profesional mempunyai keahlian dengan pengetahuan yang dimiliki dalam melayani pekerjaan. Guru yang profesional memiliki empat kompetensi yang terjalin satu dengan lainnya (Nurdiansyah, 2017)

Guru profesional sebagai salah satu unsur dominan dalam proses pendidikan sehingga pendidikan banyak ditentukan oleh kualitas tenaga pendidik dalam menjalankan peran dan kualitasnya masyarakat, guru memerlukan keahlian khusus dan tidak dapat dilakukan oleh profesi lainya.(Kalu, Rede, \& Asep, 2016).

Pekerjaan profesional dibedakan dari kelompok pekerjaan lain, karena pekerjaan profesional memiliki kemampuan menguasai pedagogik, memiliki komitmen untuk memenuhi kebutuhan klien dan Komitmen profesional dengan adanya identitas kolektif yang kuat (Muhson, 2004 ; Khairil S, 2017).

Kompetensi guru merupakan perpanduan antara kemampuan personal, keilmuan, teknologi, sosial dan spiritual yang secara menyeluruh membentuk kompetensi guru (Samsirin, 2015). Dalam mengembangkan kemampuan profesionalisme guru harus menyediakan administrasi yang berkaitan dengan proses belajar dan mengajar (Balqis, Usman, \& Ibrahim, 2014). Kompetensi guru akan mengantarkannya menjadi guru profesional yang diidamkan oleh peserta didik. Guru yang dimilki keahlian dan kemampuan ilmu memadai maka melahirkan kompetensi moral adalah dua sisi yang tidak bisa dipisahkan. 


\section{a. Kompetensi Guru}

Keberadaan guru yang profesional dan berkompetensi merupakan suatu keharusan untuk memudahkan pencapaian tujuan pembelajaran (Balqis et al., 2014). Guru yang berprofesional mampu menerima sosok keguruannya dengan wawasan yang luas dan memiliki sejumlah kompetensi yang menunjang tugasnya. Kompetensi guru merupakan seperanggkat pengetahuan, keterampilan, dan perilaku yang harus dimikili, dihayati, dikuasai, dan diwujudkan oleh guru dalam melaksanakan tugas keprofesionalnya yang ditampilkan melalui untuk kerja (Jailani, 2009).

Adapun kompetensi-kompetensi yang harus dimiliki oleh seorang guru untuk mengaktualisasikan dirinya sebagai pendidik terangkum dalam (4) kompetensi dasar seorang guru, seperti tercantum pada lampiran peraturan Mentrian Pendidikan Nasional Nomor 16 Tahun 2007 yaitu: (1) kompetensi pedagogik, (2) kompetensi kepribadian, (3) kompetensi sosial, (4) kompetensi profesional.

Kompetensi kepribadian guru meliputi: 1) bertindak sebagai norma agama, hukum, sosial dan kebudayaan nasional indonesia, 2) menampilkan diri sebagai pribadi yang jujur, berakhlak mulia, dan teladan bagi peserta didik dan masyarakat, 3) menampilkan diri sebagai pribadi yang mantap, stambil, dewasa, arif, dan berwibawa, 4) menjunjung etos kerja, tanggung jawab yang tinggi, rasa bangga menjadi guru dan percaya diri, 5) menjunjung tinggi kode etik profesi guru.

Kompetensi sosial guru meliputi: 1) bersikap Inklusif, bertindak objektif, serta tidak diskriminatif karena pertimbangan jenis kelamin, agama, ras kondisi fisik, latar belakang keluarga, dan status sosial ekonomi, 2) berkomunikasi efektif, empatik, dan santun dengan sesama pendidik, tenaga kependidikan, orang tua, dan masyarakat, 3) beradaptasi di tempat bertugas di seluruh wilayah RI yang memiliki keberagama sosial budaya, 4) berkomunikasi dengan komunikasi profesi sendiri dan profesi lain secara lisan dan tulisan atau bentuk lain.

Kompetensi profesional guru meliputi: 1) menguasai materi, struktur, konsep, dan pola pikir keilmuan yang mendukung mata pelajaran yang diampu, 2) menguasai standar kompetensi dan kompetensi dasar mata pelajaran yang diampu, 3) mengembangkan materi pembelajaran yang diampu secara kreatif, 4) 
mengembangkan keprofesional secara kelanjutan dengan melakukan tindakan reflektif, 5) memanfaatkan teknologi dan komunikasi untuk berkomunikasi dan mengembangkan diri.

\section{b. Kedudukan Guru}

Profesi guru yang secara sadar bertanggung jawab dalam mendidik, mengajar dan membimbing peserta didik (Yusutria, 2017). juga harus memiliki kemampuan untuk merancang program pembelajaran serta kemampuan menata dan mengelola kelas agar peserta didik dapat belajar dan pada akhirnya dapat mencapai tingkat kedewasaan sebagai tujuan akhir dari proses pendidikan.

Sebagai figur utama dalam proses pendidikan disekolah, guru memegang peran utama dalam menentukan keberhasilan peserta didik, terumata kaitanya dengan proses mencapai hasil belajar yang baik (Ayu, 2017). Guru merupakan komponen yang paling berpengaruh terhadap terciptanya proses dan hasil belajar yang berkualitas. Tugas utama seorang guru adalah mendidik, mengajar, membimbing, mengarahkan, melatih, dan mengevaluasi peserta didik. Dalam melaksanakan tugasnya, guru menerapkan keahlian, kemahiran yang memenuhi standar mutu atau norma tertentu yang diperoleh melalui pendidikan profesi (S, Khiril 2017) Guru profesional merupakan orang yang memiliki kemampuan dan keahlian khusus dalam bidang keguruan sehingga guru mampu melakukan tugas dan fungsinya sebagai guru dengan kemampuan maksimal (Riyadin, 2016).

Kualifikasi pendidikan guru sesuai dengan prasyarat minimal yang di temukan oleh syarat-syarat seorang guru yang profesional. Undang-undang Guru dan Dosen No. 14 Tahun 2005 jelaskan bahwa profesional adalah pekerjaan atau kegiatan yang dilakukan oleh seseorang dan menjadi sumber penghasilan kehidupan yang memerlukan keahlian, kemahiran, atau kecakapan yang memenuhi standar mutu atau norma tertentu serta memerlukan pendidikan profesi.

Hakikat guru profesional adalah guru yang mampu memberikan pelayanan yang terbaik bagi para siswanya dengan kemampuan khusus yang dimilikinya, sehingga siswa dapat menerima dan memahami penyampaian materi yang diberikan (Dewi, 2018). Seorang guru tidak hanya dituntut untuk memiliki kemampuan teknis edukatif dalam melaksanakan tugasnya, tetapi juga harus memiliki karakter yang 
dapat diandalkan sehingga dapat menjadi panutan bagi siswa, keluarga, dan masyarakat. Pembinaan karakter profesional guru mendorong pengembangan potensi guru secara terus menus dan berkesinambungan sesuai dengan kebutuhan pengajaran masing-masing guru.

\subsection{Kebijakan Peningkatan Profesionalisme Guru}

Kebijakan profesional guru yang diterapkan oleh pemerintah pusat pada akhir, akhir ini sudah menyarah pada perbaikan, akan tetap ketika penerapan yang dilaksanakan pada tingkat daerah masih dikatakan jauh tidak terkecuali pada SMP Negeri $3 \mathrm{Hu}, \mathrm{u}$, banyak kegiatan-kegiatan pengembangan guru dan mendapatkan seorang guru yang profesional yang sesuai tuntutan permen No 14 Tahun 2005, sekolah telah melaksanakan kegiatan pengembangan akan tetapi belim maksimal.

Undang-undang Guru dan Dosen Nomor 14 Tahun 2005 Guru adalah pendidik profesional dengan tugas utama mendidik,mengajar,membimbing, mengarahkan, melati, menilai dan mengevaluasi peserta didik pada pendidikan anak usia dini jalur pendidikan formal, pendidikan dasar, dan pendidikan menengan.

Dijelaskan lebih lanjut, kesadaran untuk menghadirkan guru dan tenaga kependidikan yang profesional sebagai sumber daya utama pencerdas bangsa, barangkali sama tuanya dengan sejarah peradaban pendidikan. Di Indonesia, khusus untuk guru, dilihat dari dimensi sifat dan substansinya, alur untuk mewujudkan guru yang benar-benar profesional, yaitu: (1) penyediaan guru berbasis perguruan tinggi, (2) induksi guru pemula berbasis sekolah, (3) profesionalisasi guru berbasis prakarsa institusi, dan (4) profesionalisasi guru berbasis individu atau menjadi guru madani.

\section{a. Pengembangan Keprofesian Berkelanjutan (PKB)}

Penetapan Permenneg PAN dan RB Nomor 16 tahun 2017 Tentang Pengembangan profesionalitas guru melalu Program Pengembangan Keprofesian Berkelanjutan merupakan upaya Kementrian Pendidikan dan Kebudayaan melalui Direktorat Jenderal Guru dan Tenaga Kependidikan dalam upaya peningkatann kompetensi guru telah dilakukan melalui Uji Kompetensi Guru (UKG) untuk kompetensi pedagogik dan profesional pada akhir tahun 2015. Hasil UKG menunjukkan peta profil yang menunjukan kekuatan dan kelemahann kompetensi 
guru dalam menguasaan pengetahuan pedagogik dan profesional. Peta kompetensi. Tindak lanjut pelaksanaan UKG diwujudkan dalam bentuk pelatihan guru paska UKG pada tahun 2016 dan akann dilanjutkan pada tahun2017 ini dengan program Pengembangan Keprofesian Berkelanjutan bagi guru. Tujuannya adalah untuk meningkatkan kompetensi guru sebagai agen perubahan dan sumber belajar utama bagi peserta didik. Program Pengembangan Keprofesional Berkelanjutan bagi guru dilaksanakann melalui pelatihan yang langsung menyentuh guru serta selaras dengan kebutuhan guru dalam meningkatkan kompetensinya.(Pesantren, Darul, \& Jombang, n.d,2017) Perubahan mendasar yang terkandung dalam Permenneg PAN dan RB Nomor 16 tahun 2017 dibandingkan dengan regulasi sebelumnya, di antaranya dalam hal penilaian kinerja guru yang sebelumnya lebih bersifat administratif menjadi lebih berorientasi praktis, kuantitatif, dan kualitatif, sehingga diharapkan para guru akan lebih bersemangat untuk meningkatkan kinerja dan profesionalitasnya. Dalam Permenneg PAN dan RB ini, jabatan fungsional terdiri dari empat jenjang, yaitu Guru Pertama, Guru Muda, Guru Madya, dan Guru Utama.

Setiap tahun, guru harus dinilai kinerjanya secara teratur melalui Penilaian Kinerja Guru (PK Guru) dan wajib mengikuti Pengembangan Keprofesian Berkelanjutan (PKB). PKB tersebut harus dilaksanakan sejak guru memiliki golongan kepangkatan III/a dengan melakukan pengembangan diri, dan sejak golongan kepangkatan III/b guru wajib melakukan publikasi ilmiah dan karya inovatif. Untuk naik dari golongan kepangkatan IV/c ke IV/d guru wajib melakukan presentasi ilmiah.

PKB dikembangkan atas dasar profil kinerja guru sebagai perwujudan hasil PK Guru dan didukung dengan hasil evaluasi diri. Apabila hasil PK Guru masih berada di bawah standar kompetensi yang ditetapkan atau berkinerja rendah, maka guru diwajibkan untuk mengikuti program PKB yang diorientasikan sebagai pembinaan untuk mencapai kompetensi standar yang disyaratkan. Sementara itu, guru yang hasil penilaian kinerjanya telah mencapai standar kompetensi yang disyaratkan, maka kegiatan PKB diarahkan kepada pengembangan kompetensi agar dapat memenuhi tuntutan masa depan dalam pelaksanaan tugas dan kewajibannya 
sesuai dengan kebutuhan sekolah dalam rangka memberikan layanan pembelajaran yang berkualitas kepada peserta didik.

\section{b. Esensi Kode Etik dan Etika Profesi}

Dalam melaksanakan tugas profesinya, guru Indonesia menyadari sepenuhnya bahwa perlu ditetapkan Kode Etik Guru Indonesia (KEGI) sebagai pedoman bersikap dan berperilaku yang mengejewantah dalam bentuk nilai-nilai moral dan etika dalam jabatan guru sebagai pendidik putera-puteri bangsa. KEGI yang tercermin dalam tindakan nyata itulah yang disebut etika profesi atau menjalankan profesi secara beretika.

Dengan demikian sebagai tenaga profesional, guru bekerja dipandu oleh Kode Etik. Kode Etik profesi guru dirumuskan dan disepakati oleh organisasi atau asosiasi profesi guru. Kode Etik dimaksud merupakan standar etika kerja bagi penyandang profesi guru. Di dalam UU No. 14 Tahun 2005 tentang Guru dan Dosen disebutkan bahwa "Guru membentuk organisasi atau asosiasi profesi yang bersifat independen." Organisasi atau asosiasi profesi guru berfungsi untuk memajukan profesi, meningkatkan kompetensi, karier, wawasan kependidikan, perlindungan profesi, kesejahteraan, dan pengabdian kepada masyarakat.

Sejalan dengan itu UU No. 14 Tahun 2005 tentang Guru dan Dosen mengamanatkan bahwa guru wajib menjadi anggota organisasi atau asosiasi profesi. Pembentukan organisasi atau asosiasi profesi dimaksud dilakukan sesuai dengan peraturan perundang-undangan. Pada sisi lain dijelaskan bahwa Guru dan Dosen mengamanatkan bahwa untuk menjaga dan meningkatkan kehormatan dan martabat guru dalam pelaksanaan tugas keprofesian, organisasi atau asosiasi profesi guru membentuk Kode Etik.

\subsection{Kompetensi Guru}

Guru merupakan unsur dominan dalam proses pendidikan, sehingga kualitas pendidikan banyak ditentukan oleh kualitas pendidik dalam menjalankan peran dan tugasnya di masyarakat (Mustofa, 2007). Guru adalah suatu profesi yang 
memerlukan keahlian khusus dan tidak dapat dilakukan oleh orang di luar bidang pendidikan.

PP RI nomor 74 tahun 2008 tentang guru disebutkan guru wajib memiliki kualifikasi akademik, kompetensi, sertifikat pendidik, sehat jasmani dan rohani, serta memiliki kemampuan untuk mewujudkan tujuan pendidikan nasional. (Miarso, 2008; Khairil, 2013) Menyatakan guru yang berkualitas atau yang berkualifikasi adalah yang memenuhi standar pendidik, menguasai materi atau isi pelajaran sesuai dengan standar isi, menghayati dan melaksanakan proses pembelajaran sesuai dengan standar proses pembelajaran.

Pelaksanaan pembelajaran di Indonesia sudah diupayakan agar lebih berkualitas dengan upaya meningkatkan kualitas guru baik melalui pelatihan, seminar dan melalui pendidikan formal. Dengan usaha tersebut diharapkan akan meningkatkan kualitas guru, proses pendidikan dan hasil pendidikan di Indonesia. Untuk mencapai kondisi guru yang professional, para guru harus menjadikan orientasi mutu dan profesionalisme guru sebagai etos kerja mereka dan menjadikannya sebagai landasan orientasi berperilaku dalam tugas-tugas profesinya (Sukanti, 2008; Arif 2017).

Kompetensi guru merupakan kemampuan seorang guru dalam melaksanakan kewajiban-kewajiban secara tangung jawab dan layak. Berdasarkan Peraturan Mentri Pendidikan Nasional Republik Indonesia Nomor 16 Tahun 2007 tentang Standar Kualifikasi Akademik dan Kompetensi Guru dikembangkan secara utuh dalam empat kompetensi meliputi kompetensi pedagogik, kompetensi kepribadian, kompetensi sosial dan kompetensi profesional yang diperoleh melalui pendidikan profesi.

\subsection{Implementasi Kebijakan Guru}

Menurut (Mardlotillah, 2013). Kebijakan memerlukan pertimbanganpertimbangan yang lebih jauh lagi (lebih menekankan kepada kearifan seseorang), sedangkan kebijakan lebih tepat mencakup aturan-aturan yang ada di dalamnya sehingga policy lebih diartikan sebagai kebijakan, Sedangkan kebijaksanaan merupakan pengertian dari kata wisdom (Ade, 2014). Berdasarkan pendapat tersebut, kebijakan pada dasarnya suatu tindakan yang mengarah kepada tujuan 
tertentu dan bukan hanya sekedar keputusan untuk melakukan sesuatu. Kebijakan seseorang diarahkan pada apa yang senyatanya dilakukan oleh pemerintah dan bukan sekedar apa yang ingin dilakukan oleh pemerintah.

Menurut Daryanto \& Siregar, (2017) secara umum kebijakan dikelompokkan menjadi tiga, yaitu: 1) Adanya pilihan kebijakan atau keputusan dari tindakan pemerintah yang bertujuan untuk memepengaruhi kehidupan masyarakat. 2) Adanya output kebijakan dan dimana kebijakan yang diterapkan untuk melakukan peraturan atau pengangaran, pembentuk personil dan membuat regulasi dalam bentuk program yang akan mempengaruhi kehidupan rakyat. 3) Adanya dampak kebijakan yang merupakan efek pilihan kebijakan yang mempengaruhi masyarakat.

Implementasi yang dikemukakan di atas, dapat dikatakan bahwa implementasi bukan sekedar aktivitas, tetapi suatu kegiatan yang terencanakan dan dilakukan secara tujuan kegiatan. oleh karena itu implementasi tidak berdiri sendiri tetapi dipengaruhi oleh objek berikutnya. sedangkan kebijakan pada dasarnya adalah suatu tindakan yang mengarah kepada tujuan tertentu dan bukan hanya sekedar keputusan untuk melakukan sesuatu. kebijakan diarahkan pada apa yang nyata dilakukan oleh pemerintah dan bukan sekedar apa yang ingin dilakukan oleh pemerintah.

\subsection{Kebijakan Untuk Peningkatkan Profesional Guru}

Undang-undang tentang Guru dan Dosen No 14 Tahun 2005 menjelaskan dalam meningkatkan profesional guru pemerintah menyediakan anggaran sebagaimana tercantum dibawah ini :

Pemerintah memberikan tunjangan profesi sebagaimana dimaksud dalam Pasal 15 ayat (1) kepada guru yang telah memiliki sertifikat pendidik yang diangkat oleh penyelenggara pendidikan dan/atau satuan pendidikan yang diselenggarakan oleh masyarakat. Tunjangan profesi sebagaimana dimaksud pada ayat (1) diberikan setara dengan 1(satu) kali gaji pokok guru yang diangkat oleh satuan pendidikan yang diselenggarakan oleh pemerintah atau pemerintah daerah pada tingkat, masa kerja, dan kualifikasi yang sama. Tunjangan profesi sebagaimana dimaksud pada ayat (1) dialokasikan dalam anggaran pendapatan dan belanja negara (APBN) dan/atau anggaran pendapatan dan belanja daerah (APBD). (4) Ketentuan lebih 
lanjut mengenai tunjangan profesi guru sebagaimana dimaksud pada ayat (1), ayat (2), dan ayat (3) diatur dengan Peraturan Pemerintah.(PP, 2012.). Dengan adanya kebijakan terhadap peningkatan profesi guru diharapkan dapat memberikan perubahan yang signifikan terhadap perubahan kualitas tenaga pendidik yang menetukan nasib anak bangsa untuk siap bersaing dalam skala nasional maupun skala internasional.

Kegiatan pengembangan guru yang diatur oleh pemerintah bertujuan untuk meningkatkan profesionalisme guru dalam mengabdikan dirinya sebagai tenaga pengajar yang memiliki tanggung jawab moril terhadap keberhasilan pendidikan yang diberikan kepada peserta didik, pelatihan pengembnagn diri yang diadakan oleh pemerintah merupakan suatu upaya untuk meningkatkan profresuonalisme guru seperti pelatihan MGMP, PPG, dan tes UKG sebagai penentu layak dan tidaknya seorang guru untuk mendapatkan julukan pendidik yang profesional.

\section{METODE PENELITIAN}

\subsection{Pendekatan Penelitian}

Peneliti menggunakan pendekatan deskriptif kualitatif dengan jenis penelitian studi kasus, dengan penyebaran instrumen dan untuk menggambarkan secara deskriptif fenomena-fenomena yang terjadi dilapangan. Pilihan pendekatan Deskriptif Kualitatif dengan maksud untuk memperoleh dan mendeskripsiskan fenomena-fenomena dalam"Implementasi Kebijakan Peningkatan Profesionalisme Guru SMP Negeri 3 Hu'u"

\subsection{Lokasi Penelitian}

Penelitian ini dilaksanakan di SMP Negeri $3 \mathrm{Hu}$ 'u pada semeseter Ganjil 2019/2020 di Kecamatan Hu'u Kabupaten Dompu Nusa Tenggara Barat.

\subsection{Insrumen Penelitian}

Instrumen penelitian kualitatif yaitu peneliti sendiri. Karena peneliti yang merancang dan melakukan penelitian,menganalisis data,hingga menyimpulkan hasil data.

\subsection{Data dan Sumber Penelitian}


Data dan sumber penelitian ini adalah sumber data primer dan sumber data sekunder.

a. Data primer diperoleh dari hasil observasi dan wawancara terhadap Kepala Sekolah dan Guru

b. Data sekunder digunakan untuk memperoleh data yang berupa dokumendokumen yang mendukung untuk memperkuat analisis tentang upaya dan kendala guru dalam peningkatan profesionlisme guru SMP Negeri $3 \mathrm{Hu}$ 'u.

\subsection{Tehnik Pengumpulan Data}

a. Wawancara yang dilakukan untuk memperoleh data langsung dari kepala sekolah dan guru untuk mengetahui Implementasi Kebijakan Peningkatan profesionalisme guru SMP Negeri 3 Hu'u.

b. Observasi dilakukan untuk mengumpulkan data dimana penelitian melakukan proses pengamatan, sejauh mana Implementasi Kebijakan sekolah dalam peningkatan Profesionalisme guru SMP Negeri 3 Hu'u.

c. Dokumentasi dan Informasi berupa data dokumentatif tentang Implementasi kebijakan peningkatan profesionalisme guru SMP Negeri $3 \mathrm{Hu}$ 'u. Informasi tentang upaya dan kendala dalam mengetahui Implementasi kebijakan peningkatan profesionalisme guru SMP Negeri $3 \mathrm{Hu}$ 'u

\subsection{Teknik Analisis Data}

a. Reduksi Data yang diperoleh peneliti yang berkaitan dengan bagaimana peran kepala sekolah serta kendala dan upaya dalam mengetahui Implementasi kebijakan peningkatan profesionalisme guru SMP Negeri 3 Hu'u kemudian data tersebut dirangkum di pilih data yang pokok kemudian membuang data yang tidak perlu.

b. Penyajian Data Setelah data di reduksi dengan memilih hal-hal yang di peroleh dalam penelitian, maka selanjutnya akan dilakukan tahap penyajian data dalam bentuk deskripsi tentang pencapain standar pendidik dan tenaga pendidik.

c. Penarikan Kesimpulan Selanjutnya dilakukan penarikan kesimpulan sehingga muncul temuan-temuan baru dari hasil penelitian ini berupa uraian singkat dalam bentuk deskripsi.

\subsection{Uji Keabsahan Data}


Untuk menguji validitas data dalam penelitian kualitatif ini agar data valid dan dapat di pertanggung jawabkan maka peneliti menggunakan triangulasi.Triangulasi digunakan untuk memeriksa keabsahan data dengan memanfaatkan sesuatu yang lain diluar data tersebut. Adapun triangulasi yang digunakan oleh peneliti untuk menguji kredibilitas data yaitu triangulasi dengan sumber data, dengan langkahlangkah ; 1) membandingkan data hasil pengamatan dengan data hasil wawancara ; 2) membandingkan apa yang dikatakan orang di depan umum dengan apa yang dikatakan secara pribadi ; 3) membandingkan apa yang dikatakan orang tentang situasi penelitian dengan apa yang dikatan sepanjang waktu ;dan 4) membandingkan isi wawancara dengan isi suatu dokumen yang berkaitan. Setelah peneliti melakukan penelitian dengan menggunakan metode wawancara, observasi, dan dokumentasi.

\section{HASIL PENELITIAN}

\subsection{Hasil Penelitian}

Pada bagian ini peneliti menjelaskan hasil wawancara, Implementasi Kebijakan sekolah dan hasil catatan lapangan selama penelitian. Hasil dari wawancara, analisis dokumen dan hasil catatan lapangan tersebut diharapkan dapat menjawab rumusan masalah yang telah dijabarkan oleh penulis. Data yang diperoleh dari penelitian tersebut berasal dari wawancara dengan kepala sekolah dan guru-guru. Lokasi penelitian ini di SMP Negri 3 Hu'u Kecamatan Hu'u. Kabupaten Dompu Nusa Tenggara Barat. Sekolah dipilih karena memiliki unsur yang dibutuhkan pada penelitian ini.

\subsection{Kebijakan Sekolah dalam Peningkatan Profesionalisme Guru di SMP N 3 Hu'u}

Dalam peningkatan kualitas pendidikan, sudah menjadi prioritas program sekolah yaitu kepala sekolah sebagai stakeholder utama untuk menempatkan guru pada jabatan profesional yaitu dengan membiayai kegiatan MGMP, Pelatihan K13 dan pengembangan kurikulum. Adapun hal lain yang direncanakan yaitu dengan memperbaiki sistem, menilai kinerja guru secara rutin, memberikan penghargaan 
bagi guru yang berprestasi dan memberikan sanksi bagi guru yang lalai dalam melaksanakan tugasnya. Hal tersebut sesuai dengan hasil wawancara dengan responden utama yaitu Kepala Sekolah.

"Alhamdulilah, karena sekolah ini masih tergolong sekolah yang baru didirikan tahun 2013 lalu, kami tentu memprioritaskan guru-guru di SMP Negeri 3 Hu'u dengan bekal ilmu yang berkelanjutan, kegiatan MGMP salah satunya yang sering diadakan oleh pemerintah daerah dengan tujuan mempertemukan semua guru mata pelajaran untuk sharing tentang permasalahan-permasalahan yang sering mereka hadapi. Jadi biasanya kami mengikut sertakan guru-guru kami dalam diklat guna pengembangan profesi guru. Kami sesuaikan, contohnya ketika ada kegiatan mengenai perkembangan kurikulum, yang kami utamakan adalah guru-guru kelas (VII) dan kelas (VIII), dan biasanya ketika menjelang ujian nasional itu ada pelatihan bagi guru-guru Ujian Nasional (UN), jadi kami mengirim guru-guru kelas (X) untuk ikut serta (G1.15/07/2019).”

Hasil analisis wawancara dengan kepala sekolah di SMP Negeri 3 Hu'u, kegiatan yang selalu di ikuti oleh guru-guru di sekolah tersebut adalah kegiatan MGMP. Lebih lanjut berikut ini adapun hasil wawancara bersama kepala sekolah SMP Negeri $3 \mathrm{Hu}$ 'u.

"Alhamdulilah jadi kegiatan yang sering dilakukan secara rutin di sekolah kami ini yang paling sering adalah kegiatan DIKLAT dengan tujuan untuk mengembangkan kompetensi guru untuk memenuhi kebutuhan guru tersebut secara bertahap dan berkelanjutan, kemudian ada kegiatan MGMP dengan guru-guru di sekolah lain di Kecamatan Hu'u. Nah, biasanya yang sering dibahas dalam kegiatan MGMP itu ya membahas bagaimana penyusunan perangkat kurikulum. Contohnya kurikulum yang kami pakai sekarang di sekolah yaitu K13. Adapun kegiatan lainnya yang sering kami ikuti yaitu diklat di tingkat daerah dan provinsi. Kalau di tingkat daerah kami biasa mengutus 4 atau 5 orang guru, sedangkan di tingkat provinsi, kami hanya mengutus 1 atau 2 orang guru saja (G2.15/07/2019)."

Berdasarkan hasil wawancara diatas dapat simpulkan bahwa guru-guru di

SMP Negeri 3 Hu'u selalu diikut sertakan dalam kegiatan-kegiatan yang dapat mendukung mereka untuk menjadi guru yang professional, seperti MGMP, Pelatihan, kegiatan Diklat dan Pengembangan Kurikulum. Hal tersebut juga dijelaskan juga oleh kepala sekolah :

"Alhamdulilah Kegiatan untuk menunjang keprofesian bagi guru-guru di SMP Negeri 3 Hu'u ini beragam, Bulan Juni kemaren itu ada 3 orang guru yang kami utus untuk mengikuti kegiatan Pendidikan Profesi Guru (PPG) di Mataram, kemudian ada kegiatan Pengembangan Keprofesian 
Berkelanjutan (Diklat) kami kirim beberapa guru ke Mataram juga. Kalau kegiatan PKB ini kami kirim guru yang punya golongan IIIa untuk pengembangan diri guru tersebut, seperti itu. Sedangkan yang rutin itu kegiatan MGMP. Kalau kegiatan MGMP ini semua guru kami libatkan (KS3.25/07/2019).”

kemudian Guru dalam menjalankan tugasnya sebagai seorang pendidik atau dalam melaksanakan proses belajar mengajar di dalam kelas, terlebih dahulu ia harus membuat program pembelajaran selama satu tahun, seperti pembuatan RPP, silabus, program semester, dan program tahunan. Tujuannya adalah agar setiap kegiatan dalam proses mengajar yang dilakukan guru tersebut bisa terarah. Jadi, semua guru mata pelajaran di sekolah ini diwajibkan untuk menyusun RPP dan silabus yang lengkap dan sistematis pembuatan RPP dan silabus adalah hal yang paling penting dan memang diwajibkan di sekolah kami sebelum melakukan kegiatan belajar mengajar di dalam kelas (KS4.25/07/2019)"

Kegiatan MGMP (Musyawarah Guru Mata Pelajaran) merupakan salah satu kegiatan yang membantu guru untuk mendapatkan jalan keluar dari permasalahanpermasalahan perangkat pembelajaran di sekolah, mendapatkan pengalaman baru dalam menciptakan proses belajar mengajar yang menarik dari hasil musyawarah bersama guru lainnya.

Semua guru memiliki tugas dan tanggung jawab yang sama yaitu membuat program ajar tahunan, rencana pembelajaran, melakukan kegiatan belajar mengajar di kelas. Pernyataan ini sesuai dengan hasil wawancara dengan Kepala Sekolah SMP Negeri 3 Hu'u, diantaranya sebagai berikut.

\subsection{Kendala yang dihadapi dalam Peningkatan Profesionalisme Guru}

Dalam meningkatkan profesionalisme guru, tugas kepala sekolah adalah memberikan dukungan penuh, memberikan bimbingan dan kepercayaan kepada guru-guru dalam menjalankan tanggung jawabnya sebagai seorang pendidik. Perencanaan-perencanaan yang sudah ditetapkan tidaklah selalu berjalan dengan baik, pasti selalu ada hambatan-hambatan yang ditemukan dalam pelaksanaannya.

Hal senada disampaikan oleh para guru terkait kendala guru dalam meningkatkan kompetensinya berdasarkan hasil wawancara peneliti dengan guru :

Saya sudah mengajar di SMP Negeri 3 Hu'u selama 10 tahun namun sampai saat ini saya belum memiliki NUPTK kelalaian yang dilakuakan 
oleh sekolah membuat saya harus sabar menerima hal tersebut, NUPTK merupakan jembatan buat kami untuk meraih pendidik yang profesional dimana kemampuan kami akan di ukur apabila memiliki NUPTK melalui UKG (Guru 27/07/2019)

1. Pelaksanaan MGMP, Pelatihan, Diklat, Pengembangan kurikulum di tiga sekolah tersebut masih kurang, karena tidak semua guru-guru dikirim dalam kegiatan-kegiatan tersebut. Kurangnya kesempatan untuk mengembangkan profesi secara berkelanjutan disebabkan oleh aktivitas guru yang justru terjebak pada rutinitas. Ditambah lagi dengan tidak adanya upaya pihak berwenang untuk mendorong guru ke arah pengembangan kompetensi diri ataupun karier, pihak berwenang dalam hal ini belum memberi kesempatan beasiswa maupun biaya-biaya pencerdasan guru secara luas. Dari sisi guru sendiri kurang termotivasi untuk melakukan pengembangan profesionalisme dan tergerak secara pribadi untuk mengembangkan profesinya, telebih guru yang sudah mendekati masa pensiun.

2. Kompetensi professional guru. Ketika pelatihan-pelatihan sebagai penunjang menjadi guru yang professional kurang, maka tentunya akan berdampak pada kompetensi profesional guru.

\subsection{Upaya Peningkatan Profesionalisme Guru}

Berdasarkan paparan data, diketahui bahwa berbagai upaya untuk mengatasi permasalahan baik internal maupun ekstenal. Guru harus selalu berusaha untuk melakukan penanaman pemahaman tentang standar profesi oleh kepala sekolah kepada guru melalui pembinaan rutin, membangun hubungan kesejawatan yang baik dan luas termasuk lewat organisasi profesi, mengembangkan etos kerja atau budaya kerja yang mengutamakan pelayanan bermutu tinggi kepada masyarakat, melalui pembinaan.

Alhamdulillah sekolah kami diantara sekolah lain yang sering sekali mendatangkan tutor dari luar daerah untuk pelatihan baik itu pelatihan pengembangan kurikulum maupun kegiatan pengembangan komptensi guru. Karena saya rasa meningkatkan kompetensi guru sangatlah penting bagi kemajuan generasi anak bangsa, saya terkadang menggunakan biaya pribadi untuk kegiatan ini karena saya pikir ini adalah sekolah yang saya pimpin jadi kualitas guru harus memumpuni. Saya tahu kalau biaya sekolah tidak banyak di gunakan pengembangan guru. (K.1 27/07/2019) 
Wawancara lain dengan guru

Setiap minggu antara sabtu dan Minggu kami melakukan pelatihan mandiri di sekolah dan yang menjadi tutornya pun adalah guru di sekolah kami sendiri yang sudah kepala sekolah anggap sudah memupuni dan menguasai metode pembelajaran dan sering mewakili sekolah dalam pelatihan ditingkat nasional. (Guru C 27/07/2019)

\subsection{Pengembangan Keprofesian Berkelanjutan}

Upaya yang dilakukan oleh pemerintah adalah memberikan kesempatan kepada guru untuk mengikuti seminar, bimtek dan lokakarya pengembangan profesi. Dari pihak sekolah sendiri harus membiasakan guru untuk memanfaatkan teknologi infomasi baik sebagai sarana melaksanakan tugas-tugas administrasi maupun tugas-tugas mengajar. Adapun hasil wawancara bersama kepala sekolah SMP Negeri 3 Hu'u, sebagai berikut.

Alhamdullah, memang seharusnya seperti itu, kamipun kalau misalnya ada undangan dari pihak daerah selalu kami hadiri, seperti kegiatankegiatan atau pelatihan-pelatihan yang sudah saya jelaskan tadi. Mungkin kekurangan kami adalah, kurangnya dana untuk pembiayaan guru-guru kami untuk mengikut sertakan mereka pada kegiatan PKB dan lainnya. Seperti itu ibu (KS1.27/07/2019).

Kemudian pernyataan dari kepala sekolah SMP Negeri 3 Hu'u juga dipaparkan dibawah ini.

Alhamdullah, Yang paling sering kami ikuti itu kegiatan MGMP, guruguru SMP Negeri 3 Hu'u ini kami ikut sertakan secara merata. Secara bergantian. Kalau kegiatan PKB, kami biasanya membiayai guru-guru kami (KS2. 27/07/2019).

Pernyataan yang berbeda dikatakan juga oleh kepala sekolah SMP Negeri 3 Hu'u Kalau mengenai mengikut sertakan guru-guru pada kegiatan bimtek, MGMP, PKB, itu sejauh ini sudah kami lakukan semaksimal mungkin dan sebisa kami. Akan tetapi yang namanya pelaksanaan juga tidak selalu mulus-mulus saja. Kadang, kalau sudah ada inisatif pemerintah dan sekolah untuk membiayai guru untuk ikut pelatihan ya nanti ada-ada saja kendala internal dari guru tersebut, sibuk dengan kegiatan diluar sekolah, bertabrakan dengan jam kepentingan lainnya. (KS3. 27/07/2019).

Upaya yang dilakukan oleh pihak sekolah adalah guru diberi kesempatan untuk melakukan studi banding dengan sekolah sejenis yang lebih maju, diberi 
kesempatan untuk mengikuti kuliah lanjutan, maupun kuliah penyesuaian pendidikan, dan diberi kesempatan untuk mengikuti berbagai pembinaan dan pelatihan untuk meningkatkan kompetensi guru. Pemahaman tentang standar profesi guru perlu ditanamkan kepada seluruh guru, karena guru memiliki kedudukan sebagai pendidik dan pembimbing yang tidak bisa dilepaskan dari guru sebagai pribadi. Berikut ini hasil wawancara dengan kepala sekolah SMP Negeri 3 Hu'u.

Kalau kegiatan studi banding itu, saya dan beberapa guru juga sering ikuti dan lakukan, kalau pembinaan-pembinaan lainnya ya tergantung undangan ya. Karena kami bergantung pada pemerintah daerah saja (KS1. 27/07/2019).

Hasil wawancara dengan kepala sekolah SMP Negeri 3 Hu'u.

Studi banding di sekolah-sekolah lain yang lebih maju dari kami, selalu kami ikuti juga, kadang saya sendiri, wakasek, dan guru-guru lainnya. Untuk kuliah penyesuaian bagi guru-guru juga kami biayai. Karena jika berkaitan dengan pengembangan keprofesian guru juga diperhatikan betul oleh yayasan (KS2. 27/7/2019).

Studi banding di sekolah-sekolah lain yang lebih maju dari kami, selalu kami ikuti juga, kadang saya sendiri, wakasek, dan guru-guru lainnya. Untuk kuliah penyesuaian bagi guru-guru juga kami biayai. Karena jika berkaitan dengan pengembangan keprofesian guru juga diperhatikan betul oleh yayasan (KS2. 27/07/2019).

Kepribadian guru sangat mempengaruhi peranannya sebagai pendidik dan pembimbing. Guru mendidik dan membimbing para siswa tidak hanya dengan bahan yang ia sampaikan atau dengan metode-metode penyampaian yang digunakannya, tetapi dengan seluruh kepribadiannya. Mendidik dan membimbing tidak hanya terjadi dalam interaksi formal, tetapi juga interaksi informal, tidak hanya diajarkan tetapi juga ditularkan. Pribadi guru merupakan satu kesatuan antara sifat-sifat pribadinya, dan peranannya sebagai pendidik, pengajar dan pembimbing.

\subsection{Kompetensi Profesional}

Upaya yang pertama terhadap kendala tentang menguasai materi, struktur, konsep, dan pola pikir keilmuan yang mendukung mata pelajaran yang diampu. Guru akan lebih berkonsentrasi pada profesinya, kendala yang dihadapi perlu ada 
upaya dan diperlukan kerja sama dengan semua pihak dengan mengadakan buku mata pelajaran yang bervariatif guna penguasaan materi, serta sering mengadakan MGMP tingkat kota dan sekolah. Berikut ini hasil wawancara dengan kepala sekolah dan guru SMP Negeri 3 Hu'u.

Sudah kami upayakan sebisa kami, sekarang ini juga sudah kami evaluasi kembali dari hasil pengontrolan selama satu tahun terakhir ini. Ini juga menjadi harapan sekolah untuk menjadikan guru-guru kami sebagai guru-guru yang berkualitas (KS1. 27/07/2019).

Biasanya terkait penguasaan materi itu kadang menjadi kendala disini, karna kami hanya mengharapkan 1 buku ajar saja, dan kalau mau dapat referensi lain biasanya kami beli sendiri buku, kan tidak mungkin hanya harap 1 buku dari sekolah, kasian anak-anak. Juga kami cari sumber tambahan dari internet, kan ada banyak biasanya disitu, tinggal pilih (G1.27/07/2019).

Adapun hasil wawancara dengan kepala sekolah dan guru SMP Negeri 3

Hu'u., sebagai berikut.

Biasanya kami mengadakan rapat hampar setiap hari dengan semua guru mata pelajaran tentang kendala yang mereka rasakan. Kami sharing, antara saya dan guru, maupun antara guru dengan teman gurunya (KS2. 27/07/2019).

Biasanya terkait dengan bahan ajar yang kurang, itu sangat berpengaruh pada penguasaan materi didalam kelas ya, meskipun di sekolah ini sudah lumayan bervariasi buku-buku ajarnya, tapi saya rasa itu masih kurang, saya biasanya tidak melulu mengharapkan yang dari buku itu, tidak. Saya cari lagi referensi dari internet, saya rasa sangat pas begitu kalau sudah dapat bahan dari internet

(G2. 27/07/2019).

Penelitian ini menunjukkan komponem atas upaya terhadap kendala tentang menguasai materi, struktur, konsep, dan pola pikir keilmuan yang mendukung mata pelajaran yang diampu. Menunjukkan bahwa sudah diupayakan, akan tetapi belum maksimal.

Upaya yang kedua atas kendala tentang menguasai standar kompetensi dan kompetensi dasar mata pelajaran yang diampu. Guru merupakan pelaksana dari pembelajaran dan memang hal tersebut merupakan tanggung jawabnya yang pertama dan utama. Guru membantu peserta didik yang sedang berkembang untuk 
mempelajari sesuatu yang belum diketahuinya, membentuk kopetensi dan memahami materi standar yang mempelajari (Mulyasa,2009). Berikut ini hasil wawancara dengan kepala sekolah dan guru SMP Negeri 3 Hu'u

Biasanya guru-guru disini sebelum mengajar ya mereka perlu tau dulu tentang Standar Kompetensi dari masing-masing mata pelajaran yang mereka akan ajarkan. Karena ada beberapa guru disini yang mengajar tidak sesuai dengan jurusan atau tidak sesuai gelar yang mereka dapatkan waktu kuliah. Begitu (KS1. 27/07/2019).

Saya rasa sudah menjadi tuntutan ya bagi kami disini sebelum mengajar untuk belajar terlebih dahulu, memahami standar kompetensi dan kompetensi dasar sesuai matpel yang kami ajarkan (G1. 27/07/2019).

Adapun hasil wawancara dengan kepala sekolah dan guru SMP Negeri $3 \mathrm{Hu}, \mathrm{u}$ antara lain sebagai berikut.

Wakasek kurikulum biasanya yang mengatur waktu yang terkait dengan standar kompetensi yang harus dikuasai guru-guru dan stafnya (KS2.27/07/2019).

Inisiatif sendiri kalau untuk belajar tentang mengenai standar kompetensi dan kompetensi dasar guru mata, wakasek kurikulum ya hanya mengontrol paham tidaknya kami (G2.27/07/2019).

Penelitian ini menunjukkan bahwa upaya dari kendala tentang mengembangkan keprofesionalan secara berkelanjutan dengan melakukan tindakan reflektif, guru-guru dari ketiga sekolah tersebut sudah berupaya untuk menulis karya ilmiah tetapi hal ini juga masih belum maksimal karena keterbatasan waktu yang mereka miliki.

Upaya yang kelima atas kendala tentang memanfaatkan teknologi informasi dan komunikasi untuk mengembangkan diri. Media pembelajaran merupakan salah satu usaha untuk meningkatkan profesionalisme guru untuk mengatasi kendala. Oleh karena itu solusinya yaitu: 1) alat peraga yang dipilih harus sesuai dengan kematangan dan pengalaman siswa serta perbedaan yang dipilih harus tepat, memadai, dan mudah digunakan; 3) harus direncanakan dengan teliti dan diperiksa terlebih dahulu; 4) penggunaan alat peraga disertai kelanjutannya seperti dengan diskusi, analisis, dan evaluasi; 5) sesuai batas kemampuan biaya (Usman,2006). Berikut ini hasil wawancara dengan kepala sekolah dan guru SMP Negeri 3 Hu'u 
Fasilitas yang kami punya di sekolah ini masih tergolong kurang non, seperti 1 lab di isi 20 unit computer kalau kami bandingkan dengan banyaknya siswa di sekolah ini jelas kurang. Kemudian terkait lab MIPA itu jujur kami alih fungsikan untuk ruang kelas, karena masih kekurangan gedung sekolah. Jadi alat-alat praktek Biologi, Fisika, Kimia itu untuk sementara kami masukkan dalam gudang. Ketika dibutuhkan baru dikeluarkan. Terkait jaringan internet disini ya kami punya wifi, tetapi hanya untuk guru-guru saja. Untuk siswa itu ketika mereka berada di lab computer.

Ya dengan adanya wifi disekolah ini mempermudah kami juga untuk mencari bahan ajar tambahan. Dulu kami hanya mempunyai 1 LCD, dan itu masih kurang bagi kami, karena kalau pakai LCD kan lebih bagus kalau mengajar. Sekarang sudah ada tambahan 1 lagi. Ya lumayan membantu kami juga (G1.27/07/2019).

Berikut ini hasil wawancara dengan kepala sekolah dan guru SMP Negeri 3 Hu'u

Fasilitas yang kami miliki di sekolah ini sudah cukup lengkap non, disini kami punya wifi juga ntuk mendukung proses kegiatan belajar mengajar, dilengkapi juga dengan LCD dan sound bagi guru ingin memakai LCD, ada alat lengkap di masingmasing laboratorium. Jadi kami selalu mengupayakan untuk menyediakan dan menjaga setiap fasilitas yang kami punya (KS2.27/07/2019).

Ia, sukses dan tidaknya kami mengajar di kelas ya karna faktor penunjang seperti fasilitas di sekolah kami ini cukup lengkap kak, jadi sangat menunjang sekali (G2.27/07/2019).

\section{PEMBAHASAN}

Pemerintah terus berusaha meningkatkan kualitas tenaga pendidikan nasional berbagai kebijakan, aturan yang dibuat dalam meningkatkan mutu pendidikan antara lain yang tertuang dalam PP No 19 Tahun2017 perubahan terhadap PP No 74 Tahun 2008 tentang kualifikasi tenaga pendidik yang harus dimiliki kompetensi dalam proses belajar dan mengajar.

Pada hakikatnya keberadaan sebuah lembaga sekola yang dibab tujuan untuk mengembangkan kemampuan peserta didik namun untuk terwujudnya hal demikian harus ada upaya yang dilakukan oleh guru dan kepala sekolah SMP 
Negeri 3 Hu'u mengembangkan model impletasinya harus sesuai dengan ciri khas sertak watak peserta didik jangan sampai bertolak belakang dengan keadaan peserta didik model implementasi smp 3 adalah 1) sesuai kesepakan antara guru dan kepala sekolah bahwa guru yang berjumlah harus disiplin mengikuti aturan yang di sepakati seperti datang tepat waktu ada jam dan tidaknya guru wajib kesekolah serta pulang pada jam yang telah disepakati hal ini telah terealisasi 2) kepala sekolah memerikan sanksi kepada guru apabila melanggar hal tersebut dengan memberikan Surat peringatan atau mengurangi gaji terutama pada ASN.3) kepala sekolah menerapkan model kebijakan yang unik pada sekolah tersebut dimana stiap guru yang selalu datang tepat waktu dan berkerja secara profesional sesuai tupoksi masing-masing.

Penerapan model/ kebijakan sekolah SMP Negeri $3 \mathrm{Hu}$ 'u dalam mengiplementasikan nilai-nilai budi pekerti siswa kepala sekolah mengadakan kegiatan tadarus serta siraman qolbu yang diadakan setiap hari jumat dengan penceramahnya secara kolektif bisa guru dan siswa bahkan kepala sekolah mengundang ustatz tokoh agama untuk menjadi pembicara di sekolah tersebut.

Hasil penelitian menunjukkan bahwa kebijakan sekolah dalam peningkatan profesionalisme guru SMP Negeri $3 \mathrm{Hu}$, u sudah dilaksanakan dengan maksimal. Akan tetapi, pelaksanakan MGMP, PKB, Diklat, Pengembangan Kurikulum ketiga sekolah tersebut masih kurang, karena tidak semua guru-guru dikirim dalam kegiatan-kegiatan tersebut. Kurangnya kesempatan untuk mengembangan profesi secara berkelanjutan disebabkan oleh aktivitas guru yang justru terjebak pada rutinitas. Ditambah lagi dengan adanya upaya pihak berwenang untuk mendorong guru kearah pengembangan kompetensi diri ataupun karier, pihak berwenang dalam hal ini belum memberi kesempatan beasiwa maupun biaya-biaya pencerdasan guru secara luas. Dari sisi guru sendiri kurang termotivasi untuk melakukan pengembanagan profesionalisme dan tergerak secara pribadi untuk mengembangkan profesinya,terlebih guru yang sudah mendekati masa pensiun.

Berdasarkan tugas dan tanggung jawab guru yang profesional sesuai dalam lampiran Peraturan Pendidikan Nasional Republik Indonesia No. 16 Tahun 2007 tentang Standar Kualifikasi Akademik dan Kompetensi Guru; 1) Menguasai materi, 
struktur, konsep, dan pola pikir keilmuan yang mendukung mata pelajaran yang diampu; 2) Menguasai standar kompetensi dan kompetensi dasar mata pelajaran yang diampu; 3) Mengembangkan materi pembelajaran yang diampu secara kreatif; 4) Mengembangkan keprofesionalan secara berkelanjutan dengan melakukan tindakan reflektif; 5) Memanfaatkan teknologi informasi dan komunikasi untuk mengembangkan diri.

Kompetensi profesional guru diatas dikuatkan dengan penelitian sebelumnya yaitu penelitian dari Masriani (2014) yang menyatakan bahwa: 1) penguasan materi, struktur, konsep, dan pola pikir keilmuan yang mendukung mata pelajaran yang diampu dari guru Agama Islam Sekolah Dasar Negara di Kota Taraka sudah melaksanakan dengan sempurna; 2) penguasaan standar kompetensi dan kompetensi dasar mata pelajaran yang diampu sudah melaksanakan dengan baik; 3) mengembangkan materi pembelajaran yang diampu secara kreatif guru Agama Islam tidak diperlukan lagi kemampuannnya; 4) mengembangkan keprofesionalan secara berkelanjutan dengan melakukan tindakan reflektif guru Agama Islam belum melaksanakan secara maksimal; 5) memanfaatkan dengan maksimal.

Tingkat kompetensi profesionalisme guru dalam kategori baik. Hal ini sesuai dengan pendapat (Fathurrahman, 2018) yang menyatakan bahwa, seorang guru profesional adalah orang yang memiliki kemampuan dan keahlian dalam bidang keguruan atau dengan kata lain ia telah terdidik dan terlatih dengan baik. Terdidik dan terlatih bukan hanya diperoleh pendidikan formal saja, akan tetapi harus menguasai landasan-landasan pendidikan seperti yang tercantum dalam kompetensi guru.

Kendala dalam meningkatkan kompetensi guru sebagai mana disampaikan oleh (Mulyasa, 2012) terkait dengan profesionalisme seorang guru kendala dalam memiliki metode mengajar, kendala yang berasal dari peserta didik, sumber mengajar, dan sarana prasana, kegiatan pengembangan guru yang masih kurang. Hal ini terlihat dalam proses pembelajaran serta proses pemgembangan profesi yang berlangsung di SMP Negeri 3 Hu'u Kabupaten Dompu. Upaya dn solusi yang ditawarkan dalam proses peningkatan guru telah dilakukan oleh guru untuk 
menyusaikan dengan peserta didik dan lingkungan sekolah agar terlaksana pembelajaran yang efektif dan efisien

Kondisi lapangan menunjukkan adanya keterkaitan antara teori yang telah dilapangan oleh ahlinya dengan hasil bahwa kendala tersebut harus diperhatikan dan dicari jalan keluarnya oleh seluruh pihak khususnya pemerintah. Hasil penelitian dari kendala kompetensi profesional guru SMP Negeri $3 \mathrm{Hu}$ 'u berdasarkan unsur pelaksanaan kompetensi profesional guru mendapatkan hasil; 1) Penguasaan materi, struktur, konsep, dan pola pikir keilmuan yang mendukung mata pelajaran yang ampu dari ketiga sekolah tersebut sudah cukup baik, akan tetapi belum sepenuhnya maksimal. 2) Penguasaan standar kompetensi dan kompetensi dasar mata pelajaran yang diampu sudah dilaksanakan tetapi masih kurang memenuhi standar, karena guru-guru tersebut masih mempunyai kendala dalam menguasai bahan ajar atau materi yang diampu secara keseluruhan. 3) Mengembangkan materi pembelajaran yang diampu secara kreatif sudah dilaksanakan dengan cukup baik, karena guru-guru dari ketiga sekolah tersebut terus berupaya untuk memahami buku ajar yang mereka miliki dan dengan banyak bertanya kepada guru yang sudah berpengalaman. 4) Mengembangkan keprofesionalan secara berkelanjutan dengan melakukan tindakan refleksi sudah dilaksanakan dengan cukup baik, karena guru-guru dari ketiga sekolah tersebut sudah berupaya untuk menulis karya ilmiah tetapi hal ini juga masih belum maksimal karena keterbatasan waktu yang mereka miliki. 5) memanfaatkan teknologi informasi dan komunikasi untuk mengembangkan diri kurang memenuhi ketentuan yang ditetapkan, karena masih ada beberapa sekolah yang masih kekurangan fasilitas belajar sebagai penunjang kegiatan belajar mengajar di dalam kelas.

Upaya yang dilakukan terhadap kendala peningkatan profesionalisme guru di SMP Negeri 3 Hu'u menunjukan hasil penelitian sudah dilaksanakan, tetapi hasil yang telah dilaksanakan belum tercapai secara maksimal.

Kondisi lapangan menunjukkan dari upaya peningkatan profesionalisme guru belum maksimal. Hal ini dilaksanakan juga oleh peneliti sebelumnya Fachruddin (2014) yang menyatakan bahwa upaya peningkatan kompetensi guru 
UN yang dilaksanakan di sekolah juga akan memberikan hasil yang sesuai dengan kinerja yang telah dilaksanakan selama ini. Hasil tersebut dapat bernilai maksimal atau minimal. Namun semua pihak sekolah dari kepala sekolah, guru, maupun peserta didik akan selalu berharap untuk mendapatkan hasil yang sesuai.

Guru yang ditugaskan untuk mendidik generasi penurus bangsa dituntut untuk memiliki sikap dan prilaku yang baik, menunjukan sikap ramah yang dapat baru dan digugu oleh peserta didik untuk mendapatkan nilai ini guru harus memiliki rasa cinta terhadap profesi yang dimilikinya bahwa guru memiliki tanggung jawab yang benar terhadap kemampuan anak bangsa (Sujoko, 2017).

\section{KESIMPULAN DAN SARAN}

1. Dari hasil analisis Implementasi Kebijakan Peningkatan Profesionalisme Guru di SMP Negeri 3 Hu'u Kabupaten Dompu dapat diajurkan hal-hal sebagai berikut.

Pertama pelaksanaan terkait dengan peningkatan profesionalisme guru di SMP Negeri 3 Hu'u sudah dilaksanan dengan maksimal. Akan tetapi, pelaksanakan MGMP, PKB, Diklat, pengembangan kurikulum sekolah tersebut masih kurang,. Kurangnya kesempatan untuk mengembangkan profesi secara berkelanjutan disebabkan oleh aktivitas guru yang terjebak pada rutinitas. Sepeti pembuatan Rencana Pelaksanaan Pembelajaran berkaiatan dengan program proses pembelajaran serta sarana dan prasana penunjung kegiatan PKBM.

Kedua dari sisi guru sendiri kurang termotivasi untuk melakukan pengembanagan profesionalisme dan tergerak secara pribadi untuk mengembangkan profesinya,terlebih guru yang sudah mendekati masa pensiun.

2. Kendala yang di hadapi dalam Peningkatan Profesionalisme Guru SMP Negeri 3 Hu'u terkain dengan. Kemampuan guru dalam upaya peningkatan kualitas pendidikannya masih tergolong kurang, kepekaan guru terhadap profesinya masih terus ditingkatkan, kebijakan sekolah untuk para GTT yang belum memiliki NUPTK masih belum maksimal, guru mengundur waktu dalam berbagai kegiatan pengembangan guru, masih ada tingkat 
kesalahan dalam pengelolaan perangkat pembelajarn dan belum maksimal akan tetapi kendala tersebut tidak serta merta datang dari guru melaikan dari peserta didik juga yang terkadang melakukan tingkat kesalahan yang fatal, peserta didik ketika guru menyampaikan materi terkadang tidak didengar dan asyik ngobrol sendiri dalam kelas. Untuk meminimalisir kesalahan ini maka diharapkan mencari solusi secara bersama.

3. Upaya yang dilakukan untuk peningkatan profesionalisme guru SMP negeri 3 Hu'u yaitu: 1) Pelatihan pengembangan guru yang dilakukan perpekan di Sekolah tersebut; 2) Pelatihan pada tingkat Kabupaten, Workshop, belajar kelompok bimbingan guru; 3) Tata tertib guru serta Tata tertib siswa yang harus diikuti oleh seluruh guru dan peserta didik yang berada di Sekolah SMP Negeri 3 Hu'u.

\section{SARAN}

Berdasarkan hasil penelitian dan pembahasan bahwa analisis pengumpulan data dapat dijadikan masukan bagi pemerhati pendidikan untuk segera menindaklanjuti tentang kekurangan dari peningkatan profesionalisme guru di SMP Negeri $3 \mathrm{Hu}$ 'u. Peneliti memberikan saran sebagai berikut.

1. Bagi guru, hendaknya mengembangkan kemampuan dalam memenuhi tuntutan kinerjanya, meningkatkan kemampuan dalam membuat program pembelajaran yang menarik agar peserta didik tidak merasa bosan, guru hendaknya terus mengikuti pelatihan-pelatihan pengembangan dirinya, dan guru hendaknya bisa memanfaatkan teknologi dengan baik sebagai sumber tambahan referensi.

2. Bagi Peserta didik, hendaknya selalu mengikuti pearturan yang telah disepakati bersama antara guru dan peserta didik bahwa peserta didik adalah anak dari guru-gur tersebut ketika berada dalam lingkungan sekolah. Peserta didik hendaknya mengikuti kegiatan pembelajaran dengan tertib dan aktif sehingga bakat dan potensinya bisa diasah, sebagai bentuk keberhasilah guru.

3. Bagi Kepala sekolah, hendaknya dapat mengambil sikap yang tegas terhadap kesalah yang dilakukan oleh guru, kepala sekolah hendaknya cepat dalam 
memecahkan masalah yang dihadapi oleh guru dalam kaitannya dengan permasalahan pemebelajaran yang melibatkan peserta didik, kepala sekolah hendaknya menjadi teladan bagi para guru di sekolah tersebut dan bisa dijadikan inspirasi dalam tingkat kedisiplinan.

\section{RUJUKAN}

Ade, I. (2014). Analisis Implementasi Kebijakan Tunjangan Profesi Guru di SMA Negera 1 Palu. Jurnal Jipsindo, 1(1), 59-77.

Ayu, I. G., Damayanthi, E., Agung, A., Agung, G., \& Suarni, N. K. (2017). Profesional Ditinjau Dari Output Institusi Pada Para Guru Smp Negeri Di Kota Denpasar.

Balqis, P., Usman, N., \& Ibrahim, S. (2014). Kompetensi Pedagogik Guru Dalam Meningkatkan Motivasi Belajar Siswa Pada. Jurnal Administrasi Pendidikan Pascasarjana Univeritas Syiah Kuala, 2(1), 25-38. https://doi.org/10.1093/rfs/hhn039

Daerah, P. (2012). Presiden republik indonesia.

Daryanto, E., \& Siregar, N. (2017). IMPLEMENTASI KEBUIJAKAN KEPALA SEKOLAHDALAM MENINGKATKAN PROFESIONALISME GURU DI SMA NEGERI 3 MEDAN, $X(1), 24-38$.

Dewi, C. (2018). IMPLEMENTASI KEBIJAKAN PEMERATAAN GURU DALAM MENINGKATKAN MUTU PENDIDIKAN. DOI, 1(2), 60-69. https://doi.org/10.31002/ijel.v1i2.649

Dwi Kesuma Putri, A., Imaniyati, N., \& Studi Pendidikan Manajemen Perkantoran, P. (2017). Pengembangan Profesi Guru Dalam Meningkatkan Kinerja Guru (Professional Development of Teachers in Improving the Performance of Teacher). Jurnal Pendidikan Manajemen Perkantoran, 1(1), $1-10$.

Fathurrahman, F. (2018). Peningkatan Profesionalisme Guru Bahasa Melalui Supervisi Pengajaran Kepala Sekolah. Jurnal Reforma, 7(1), 25-36. https://doi.org/10.30736/rfma.v7i1.38

Guru, A. P., Guru, P. P., \& Inggris, K. (1996). BAB II KAJIAN TEORI A. Profesionalisme Guru 1. Pengertian Profesionalisme Guru, 26-70.

Hasbullah. (2015). No Title. Profesi Kependidikan, 1-12.

Jailani, M. S. (2009). Guru Profesional d an Tantangan Dunia Pendidikan, 1-9.

Kalu, M. R., Rede, A., \& Asep, H. (2016). Kompetensi Pedagogik Dan Profesional Guru Sekolah Dasar Yang Tersertifikasi Pada Pembelajaran 
Sains. Jurnal Sains Dan Teknologi Tadulako, 5(3), 85-94.

Lion, E. (2015). No Title. Kemampuan Profesi Guru Dalam Pembelajran Efektif, $1-8854 / 6 y((3) 1), 1-8$.

Mardlotillah, F. (2013). Implementasi Kebijakan Sekolah dalam Upaya Pengembangan Pendidikan Karakter melalui Program Pembiasaan Membaca Al- Qur' an. Kebijakan Dan Pengembangan Pendidikan, 1(2), 150-155.

Miarso, Y. (2008). Peningkatan Kualifikasi Guru dalam Perspektif Teknologi Pendidikan. Jurnal Pendidikan Penabur, 7, 6676. https://doi.org/10.1017/CBO9781107415324.004

Mustofa. (2007). Upaya Pengembangan Profesionalisme Guru Di Indonesia. Jurnal Ekonomi \& Pendidikan, 4(April), 62-75.

Nurdiansyah, A. S. (2017). Profesionalisme Guru dan Tantangan Kedepan dalam Peningkatan Mutu Pendidikan Pada Era Global. Universitas Negeri Malang, (180), 180-190.

Pesantren, U., Darul, T., \& Jombang, U. (n.d.). PERAN BIROKRASI Mujianto Solichin Pendahuluan Mengawali perbincangan topik tentang "Implementasi kami mengutip pendapat Syaefudin Sa "e ud dan Abin Syamsuddin " Kekuasaan kebijakan mencakup setiap hukum yang atau setiap individu di dalamnya, apakah berka, 6, 148-178.

Riyadin, S. (2016). Kebijakan Pengembangan Profesioanlisme Guru PNS. Jurnal JKMP, 4(2), 219-234.

S, K. (2017). No Title. Profesionalisme Guru Dalam Meningkatkan Kualitas Sumber Daya Manusia, 38-45(2(1)), 1-10.

Samsirin. (2015). Konsep Mutu dan Kepuasan Pelanggan dalam Pendidikan Islam. At-Ta'dib, 10(1).

Studi, P., \& Matematika, P. (2017). PROFESIONALISME GURU, 2(1), 38-46.

Sujendra Diputra, K., \& Ketut Desia Tristiantari, N. (2016). Mengembangkan Profesionalisme Guru-Guru Ipa Melalui Pendampingan Lesson Study. Jurnal Widya Laksana, 5(2), 1410-4369.

Sukanti. (2008). MENINGKATKAN KOMPETENSI GURU MELALUI PELAKSANAAN PENELITIAN TINDAKAN KELAS. Jurnal Pendidikan Akuntansi Indonesia, VI(2), 1-10.

Wulandari, R. W. (2016). Kompetensi Pedagogik Dan Profesional Guru Fisika Dalam Melaksanakan Pendekatan Saintifik Di SMAN Sleman. Jpfk, 2(2), 92-104. 
Lampiran 1. Daftar Dokumen

DAFTAR DOKUMEN

$\begin{array}{ll}\text { Dokumen } & : \\ \text { Nomor kode } & : \\ \text { Diringkas } & : \\ \text { Waktu } & \text { : }\end{array}$

\begin{tabular}{|c|l|}
\hline No & \multicolumn{1}{|c|}{ Jenis Dokumen } \\
\hline 1 & $\begin{array}{l}\text { Manajemen } \\
\text { a. Rumusan visi dan misi } \\
\text { b. Kebijakan sekolah } \\
\text { d. Notulen dan agenda rapat } \\
\text { Data Kesiswaan } \\
\text { a. Jumlah kelas dan jumlah siswa } \\
\text { b. Jumlah pendaftar dan jumlah yang diterima tahun terakhir } \\
\text { Data ketenagaan } \\
\text { a. Kepala sekolah beserta biodatanya } \\
\text { b. Guru (tingkat pendidikan, pengalaman, dan tugas,dsb) } \\
\text { c. Staf/karyawan (tingkat pendidikan beserta rincian tugasnya) } \\
\text { d. Jumlah Guru } \\
\text { e. Jadwal guru dan mata pelajaran } \\
\text { Organisasi } \\
\text { a. Struktur organisasi sekolah dan rincian tugas } \\
\text { b. Kumpulan Surat-surat Keputusan dan Surat Tugas } \\
\text { Pedoman dan Peraturan-peraturan } \\
\text { a. Deskripsi tugas kepala sekolah, guru, dan staf } \\
\text { b. Pedoman/peraturan guru } \\
\text { c. Pedoman peraturan akademik siswa } \\
\text { d. Peraturan tata tertib sekolah } \\
\text { Sarana Prasarana Sekolah } \\
\text { a. Denah lokasi sekolah } \\
\text { b. Gedung dan ruang sekolah } \\
\text { c. Sarana dan alat-alat pembelajaran } \\
\text { d. Sarana dan fasilitas penunjang lainnya } \\
\text { Proses Belajar mengajar } \\
\text { a. Jadwal pelajaran, mata pelajaran } \\
\text { b. Kurikulum } \\
\text { Data Dari Kepala Cabang Dinas }\end{array}$ \\
\hline
\end{tabular}


Lampiran 2. Daftar Observasi

\title{
DAFTAR OBSERVASI
}

\author{
Tanggal Pengamatan : \\ Tempat : SMP Negeri 3 Kecamatan Hu'u \\ Pengamatan : \\ Pengamat : Qurban Hajar \\ Ruang/Waktu : \\ Kegiatan : \\ Peristiwa
}

Setting dan Peristiwa yang diamati:

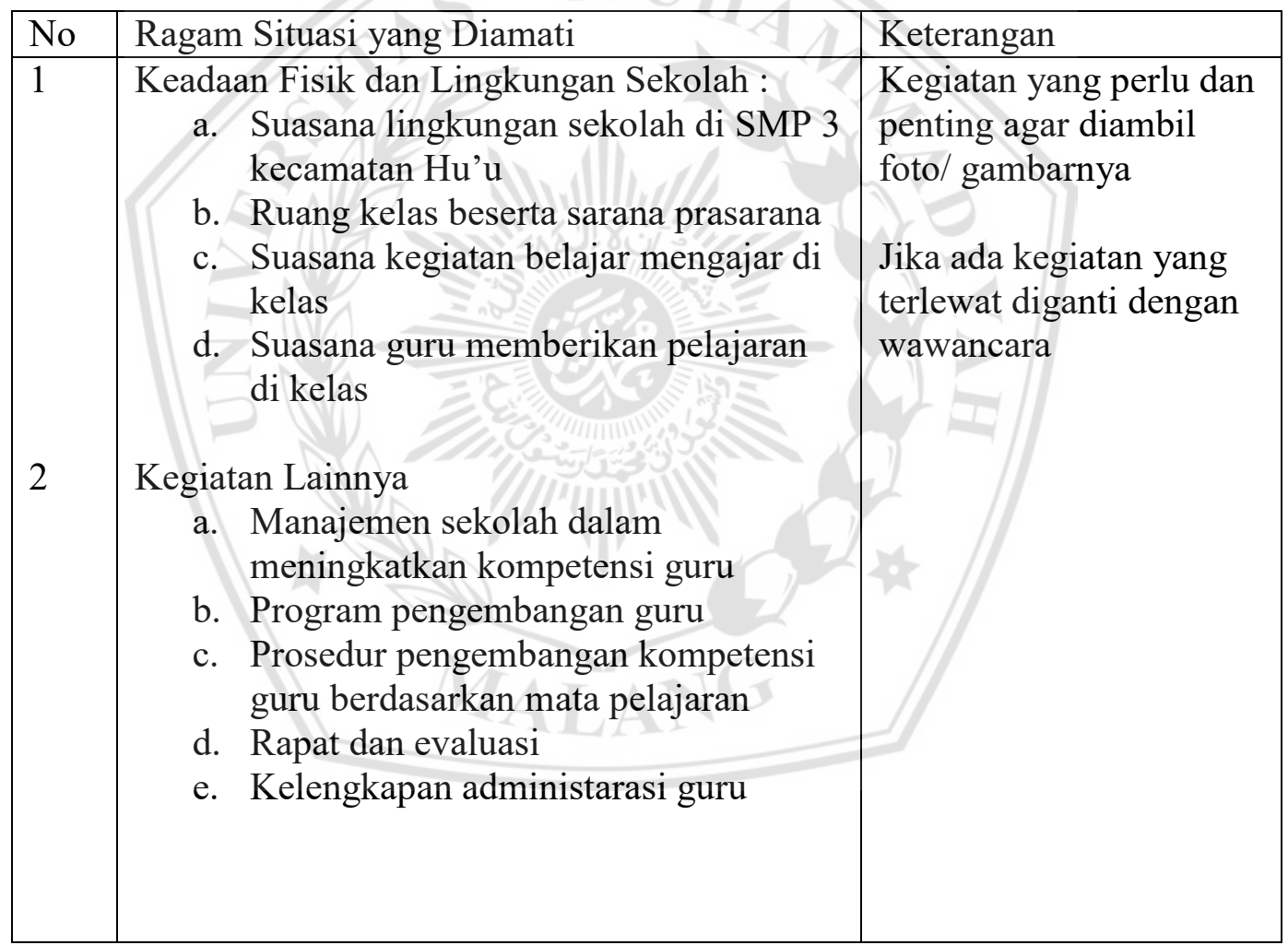


DAFTAR PERTANYAAN

WAWANCARA MENDALAM

\section{IMPLEMENTASI KEBIJAKAN PENINGKATAN PROFESIONALISME GURU SMP NEGERI 3 HU'U KECAMATAN HU'U KABUPATEN DOMPU}

\begin{tabular}{|c|c|c|c|}
\hline Sub Fokus Penelitian & Aspek/ Indikator & $\begin{array}{c}\text { Pertanyaan } \\
\text { Penelitian }\end{array}$ & Informan \\
\hline $\begin{array}{l}\text { Pelaksanaan kebijak } \\
\text { an pengembangan } \\
\text { profesi guru }\end{array}$ & 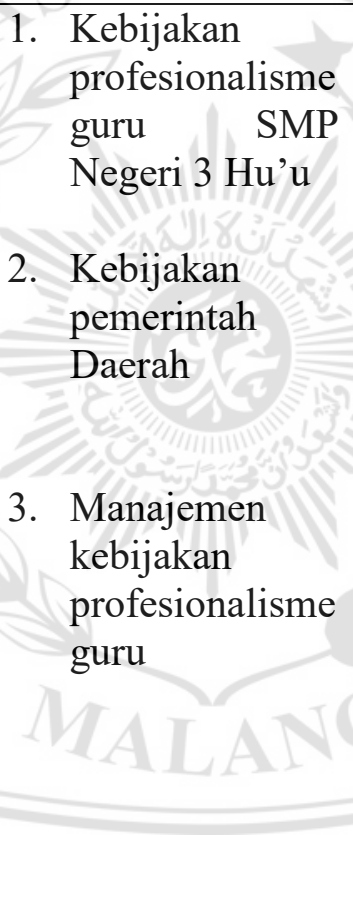 & 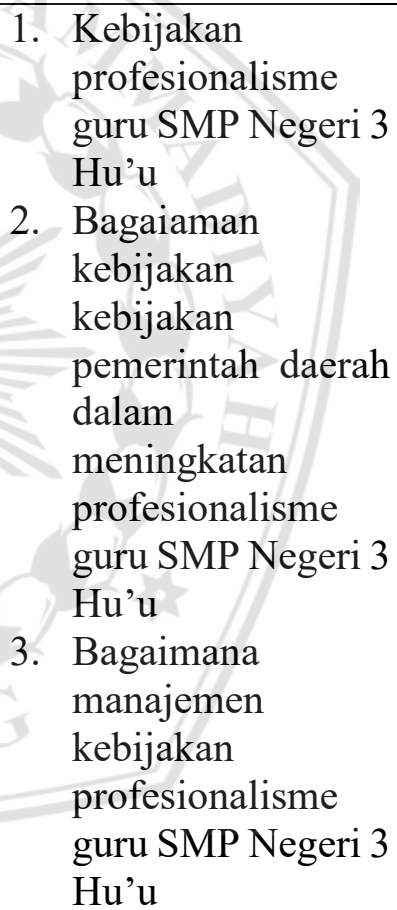 & $\begin{array}{l}\text { Kepala } \\
\text { sekolah/guru }\end{array}$ \\
\hline $\begin{array}{l}\text { pengembangan } \\
\text { profesionalisme guru }\end{array}$ & $\begin{array}{l}\text { 1. implementasi } \\
\text { kebijakan } \\
\text { profesionalisme } \\
\text { guru SMP } \\
\text { Negeri } 3 \mathrm{Hu} \text { 'u }\end{array}$ & $\begin{array}{l}\text { 1. Bagaimana } \\
\text { implementasi } \\
\text { kebijakan } \\
\text { pengemnagan } \\
\text { profesionalisme } \\
\text { guru SMP Negeri } 3 \\
\text { Hu'u }\end{array}$ & $\begin{array}{l}\text { Kepala } \\
\text { sekolah/guru }\end{array}$ \\
\hline $\begin{array}{l}\text { Kendala dalam } \\
\text { meningkatkan } \\
\text { profesionalisme guru } \\
\text { SMP Negeri 3 Hu'u }\end{array}$ & $\begin{array}{l}\text { 1. Kualitas guru } \\
\text { 2. Kurikulum }\end{array}$ & $\begin{array}{l}\text { 1. Bagaiman } \\
\text { kemampuan guru } \\
\text { dalam proses } \\
\text { belajar mengajar }\end{array}$ & Guru \\
\hline
\end{tabular}




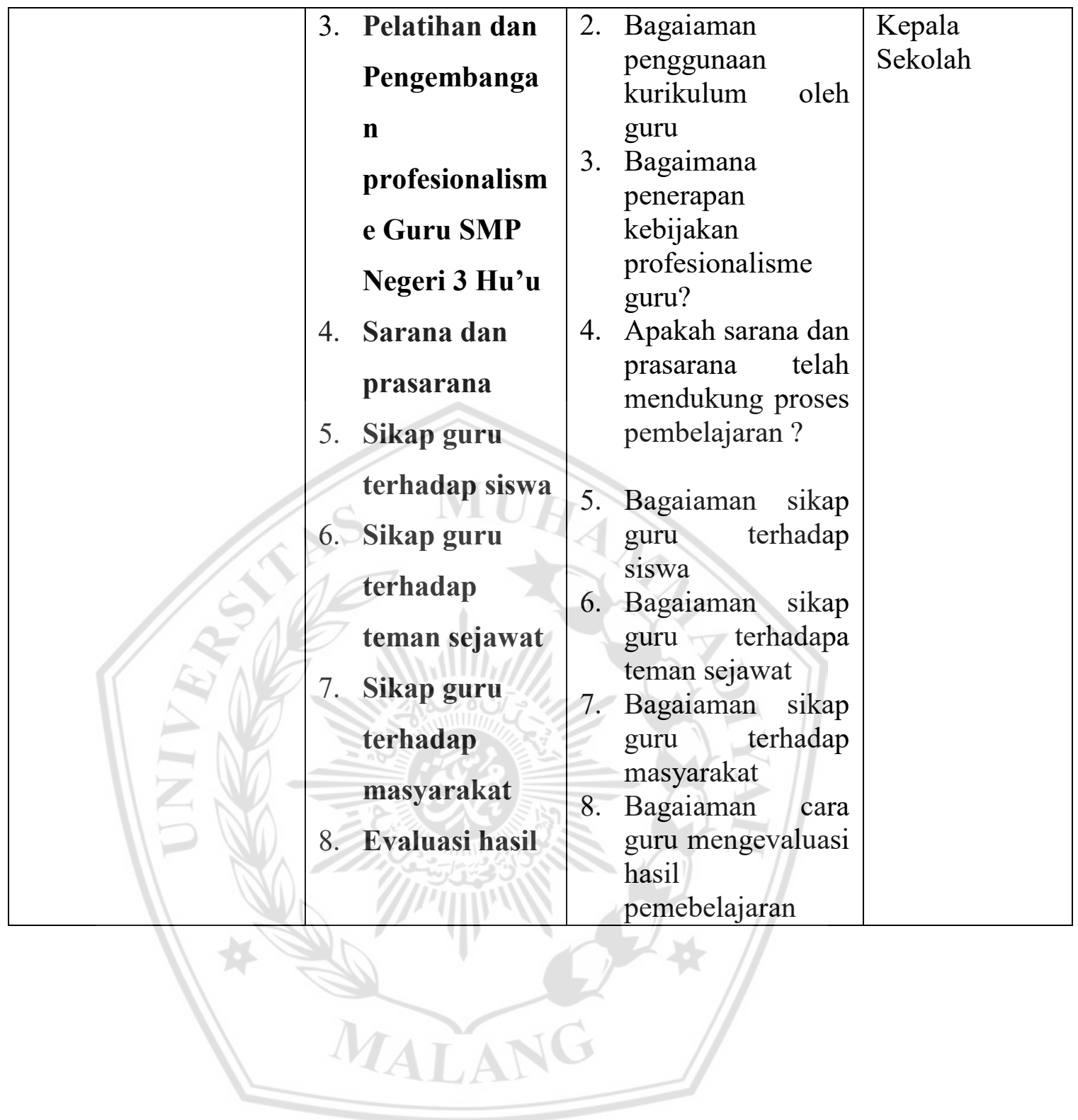



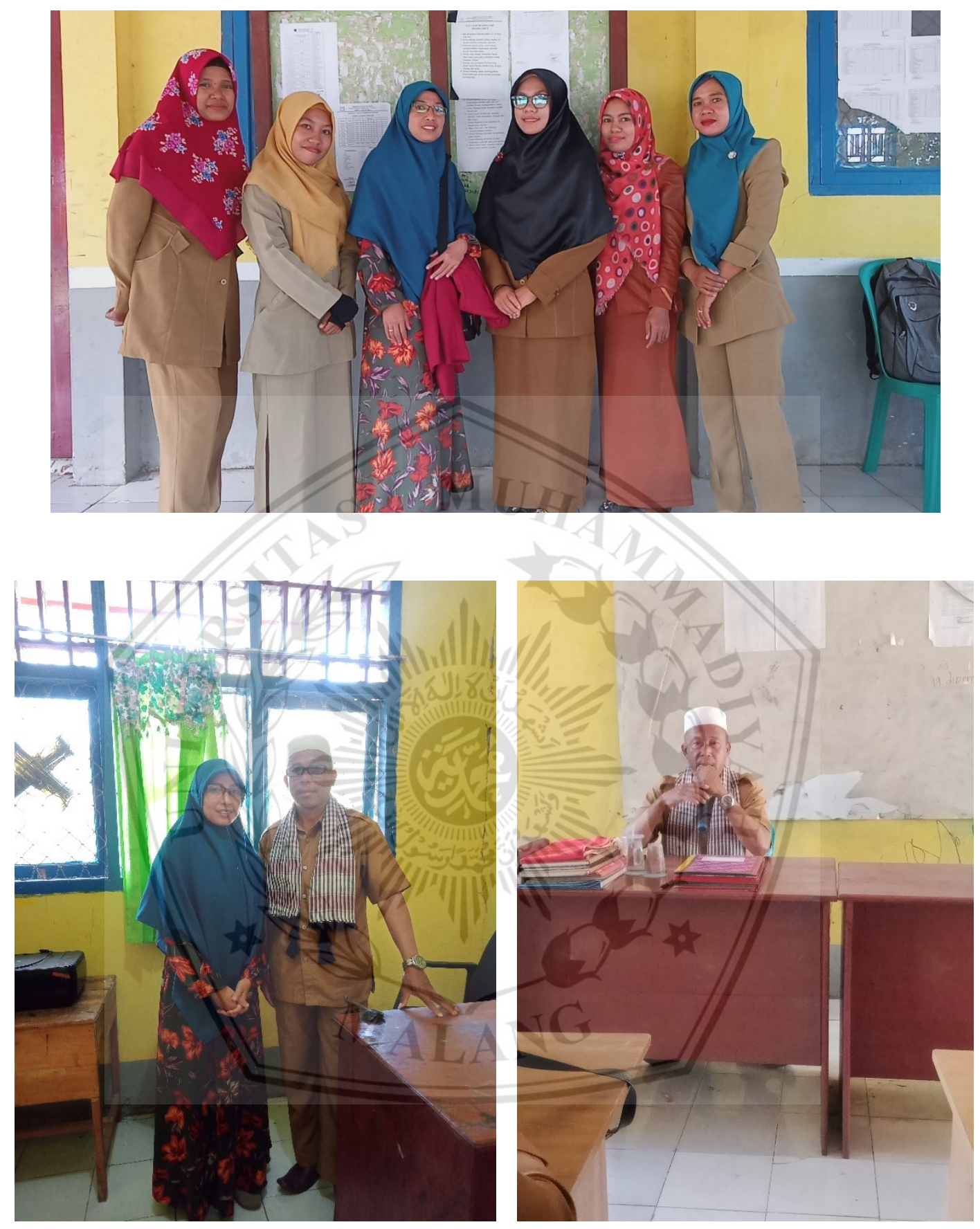

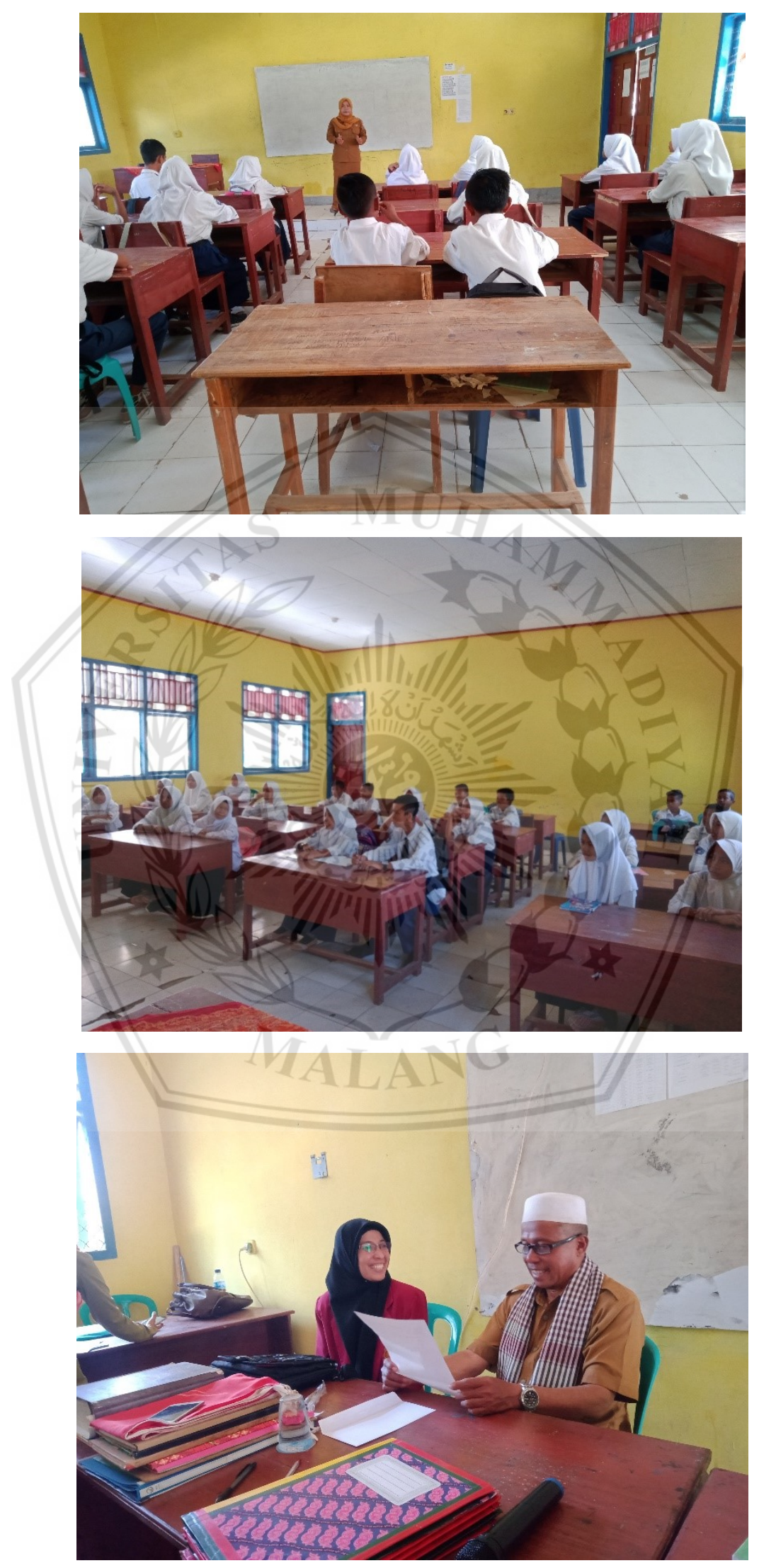

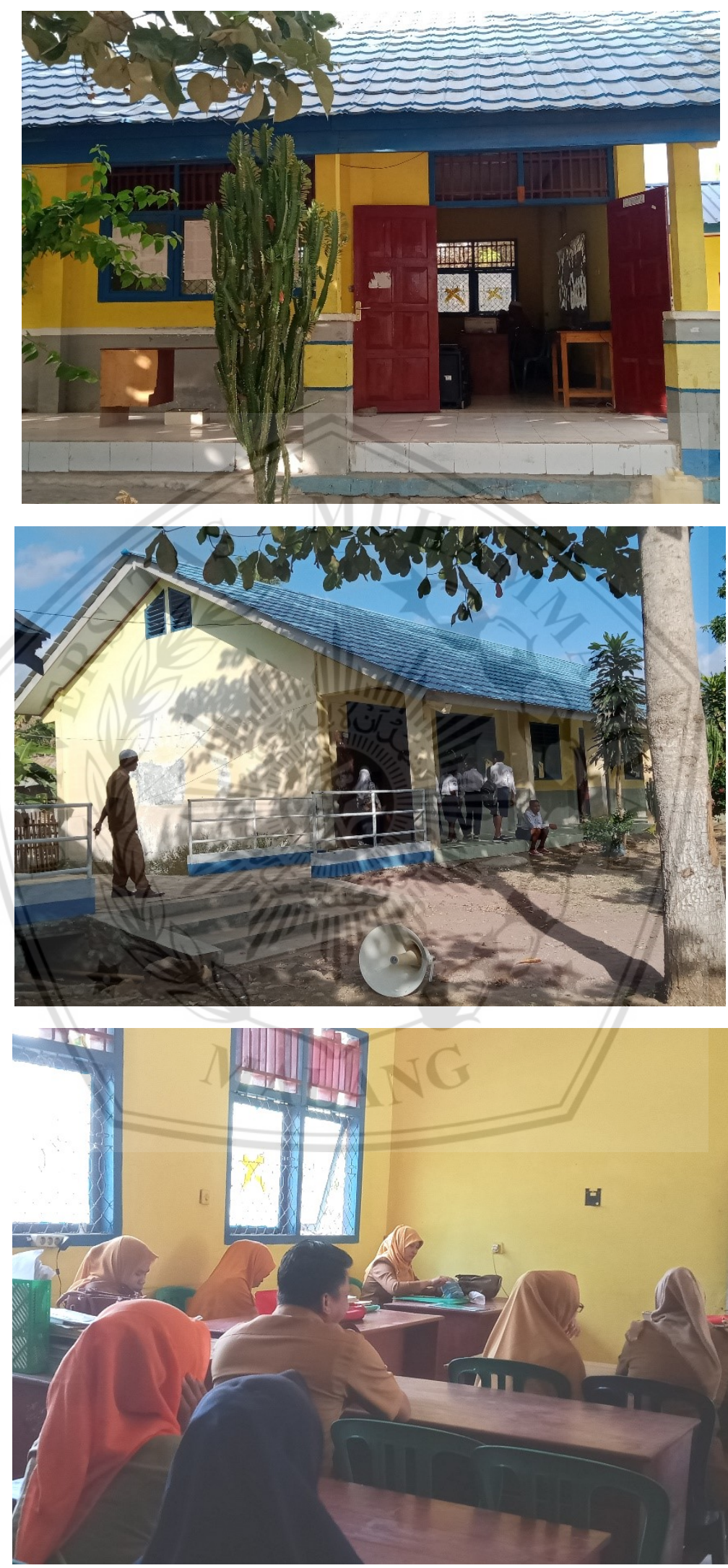


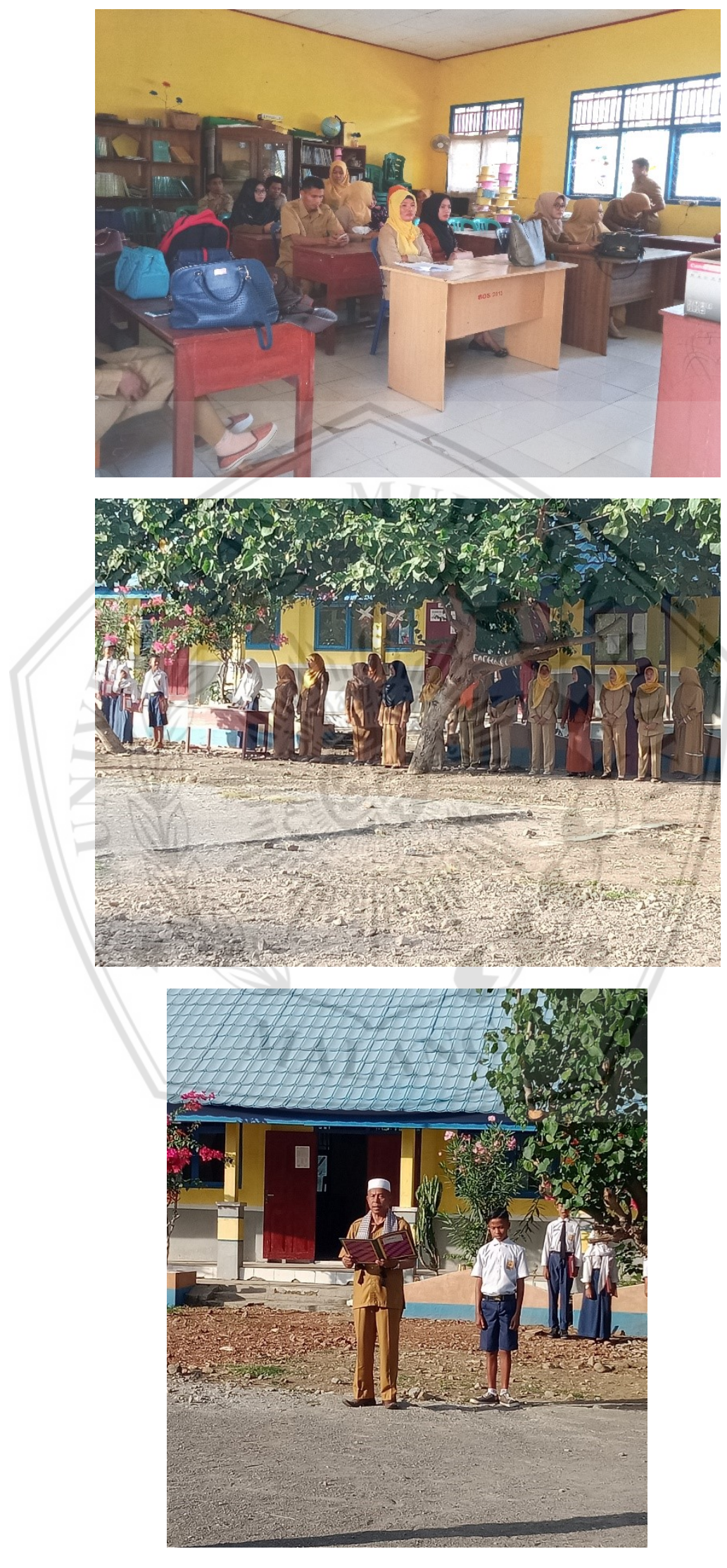

